\title{
A 2-D process-based model for suspended sediment dynamics: a first step towards ecological modeling
}

\author{
F. M. Achete ${ }^{1}$, M. van der Wegen ${ }^{1,2}$, D. Roelvink ${ }^{1,2,3}$, and B. Jaffe ${ }^{4}$ \\ ${ }^{1}$ UNESCO-IHE, Delft, the Netherlands \\ ${ }^{2}$ Deltares, Delft, the Netherlands \\ ${ }^{3}$ Delft University of Technology, Delft, the Netherlands \\ ${ }^{4}$ US Geological Survey Pacific Science Center, Santa Cruz, California, USA \\ Correspondence to: F. M. Achete (f.achete@unesco-ihe.org)
}

Received: 20 December 2014 - Published in Hydrol. Earth Syst. Sci. Discuss.: 02 February 2015

Revised: 29 May 2015 - Accepted: 01 June 2015 - Published: 19 June 2015

\begin{abstract}
In estuaries suspended sediment concentration (SSC) is one of the most important contributors to turbidity, which influences habitat conditions and ecological functions of the system. Sediment dynamics differs depending on sediment supply and hydrodynamic forcing conditions that vary over space and over time. A robust sediment transport model is a first step in developing a chain of models enabling simulations of contaminants, phytoplankton and habitat conditions.

This works aims to determine turbidity levels in the complex-geometry delta of the San Francisco estuary using a process-based approach (Delft3D Flexible Mesh software). Our approach includes a detailed calibration against measured SSC levels, a sensitivity analysis on model parameters and the determination of a yearly sediment budget as well as an assessment of model results in terms of turbidity levels for a single year, water year (WY) 2011.

Model results show that our process-based approach is a valuable tool in assessing sediment dynamics and their related ecological parameters over a range of spatial and temporal scales. The model may act as the base model for a chain of ecological models assessing the impact of climate change and management scenarios. Here we present a modeling approach that, with limited data, produces reliable predictions and can be useful for estuaries without a large amount of processes data.
\end{abstract}

\section{Introduction}

Rivers transport water and sediments to estuaries and oceans. Sediment dynamics will differ depending on sediment supply and hydrodynamic forcing conditions, both of which vary over space and time. The human impact on sediment production dates from 3000 years ago, and has been accelerating over the past 1000 years due to considerable engineering works (Syvitski and Kettner, 2011). Milliman and Syvitski (1992) estimated that the budget of sediment delivered to the coastal zone varies between 9.3 and $58 \mathrm{Gt}$ per year. Estimating the world sediment budget is still a challenge because of the lack of data and detailed modeling studies (Vörösmarty et al., 2003). In addition, there is considerable uncertainty in hydraulic forcing conditions and sediment supply dynamics due to variable adaptation timescales over seasons and years (such as varying precipitation and river flow), decades (such as engineering works) and centuries to millennia (sea level rise and climate change).

Examples of anthropogenic changes influencing sediment dynamics in river basins and estuaries are manifold, e.g., the San Francisco Bay and the inland Sacramento-San Joaquin delta (Bay-Delta system) (Schoellhamer, 2011) and Yangtze estuaries (Yahg, 1998), and the Mekong Delta (Manh et al., 2014). These three systems are similar in how anthropogenic changes altered sediment supply. After an increase in sediment supply (due to hydraulic mining and deforestation) each had a steep drop in sediment discharge (30\% or more) due to reservoir building and further estuarine clearing after depletion of available sediment in the bed. This implies (a) con- 
tinuous change in sediment dynamics and hence sediment budget in the estuary, and (b) change in sediment availability leading to change in turbidity levels.

Turbidity is a measurement of light attenuation in water and is a key ecological parameter. Fine sediment is the main contributor to turbidity. Therefore, suspended sediment concentration (SSC) can be translated into turbidity by applying empirical formulations. Besides SSC, algae, plankton, microbes and other substances may also contribute to turbidity levels (ASTM International, 2002). High turbidity levels limit photosynthesis activity by phytoplankton and microalgae, therefore decreasing associated primary production (Cole et al., 1986). Turbidity levels also define habitat conditions for endemic species (Davidson-Arnott et al., 2002). For example, in the San Francisco Bay-Delta estuary the delta smelt seeks regions where the turbidity is between 12 and 18 NTU to hide from predators (Baskerville and Lindberg, 2004; Brown et al., 2013). Examples of other ecological impacts related to SSC are vegetation stabilization (Morris et al., 2002; Whitcraft and Levin, 2007), and salt marsh survival under sea level rise scenarios (Kirwan et al., 2010; Reed, 2002).

To assess the aforementioned issues, the goal of this work is to provide a detailed analysis of sediment dynamics including (a) SSC levels in the Sacramento-San Joaquin delta (Delta), (b) sediment budget and (c) translation of SSC to turbidity levels using a two-dimensional horizontal, averaged in the vertical (2DH), process-based, numerical model. The $2 \mathrm{DH}$ model solves the $2-\mathrm{D}$ vertically integrated shallow-water equations coupled with advectivediffusive transport. This process-based model will be able to quantify high-resolution sediment budgets and SSC, both in time ( $\sim$ monthly/yearly) and space ( $\sim 10-100$ s of meters). We selected the Delta area as a case study, since the area has been well monitored so that detailed model validation can take place, it hosts endemic species, and allow us to use a 2DH model approach.

The Delta and Bay are covered by a large survey network with freely available data on river stage, discharge and SSC and other parameters from the US Geological Survey (USGS) (nwis.waterdata.usgs.gov), Californian Department of Water Resources (http://cdec.water.ca.gov/) and National Oceanic and Atmospheric Administration (http:// tidesandcurrents.noaa.gov/). The continuous SSC measurement stations are periodically calibrated using water collected in situ, that is filtered and weighed in the laboratory. In addition, the Bay-Delta system has high-resolution $(10 \mathrm{~m})$ bathymetry available for all the channels and bays (http://www.d3d-baydelta.org/).

Regarding ecological value, starting from the bottom of the food web, the Delta is the most important area for primary production in the San Francisco estuary. The Delta is 1 order of magnitude more productive than the rest of the estuary (Jassby et al., 2002; Kimmerer, 2004). It is an area for spawning, breeding and feeding for many endemic species of fishes and invertebrates, including some endangered species like delta smelt (Brown et al., 2013), chinook salmon, spring run salmon and steelhead. Additionally, several projects for marsh restoration in the Delta are planned and the success of these projects depends on sediment availability (Brown, 2003).

SSC spatial distribution and temporal variability is important information for the ecology of estuaries. However, observations including both high spatial and temporal resolution of SSC are difficult to make, so we revert to using coupled hydrodynamic-sediment transport models to make predictions at any place and time.

For the first time, a detailed, process-based model is developed for the San Francisco Bay-Delta, to focus on the complex delta sediment dynamics. From this model it is possible to describe the spatial sediment (turbidity) distribution and deposition patterns that are important indicators to assess habitat conditions. Seasonal and yearly variations in sediment dynamics and turbidity levels can be used as indicators for ecological modeling (Janauer, 2000). This work fills the gap between the physical aspects (hydrodynamic and sediment modeling) and ecology modeling. Previous work focused on understanding the San Francisco Bay-delta system through data analysis (Barnard et al., 2013; Manning and Schoellhamer, 2013; McKee et al., 2006, 2013; Morgan-King and Schoellhamer, 2013; Schoellhamer, 2002, 2011; Wright and Schoellhamer, 2004, 2005), while similar work in other estuaries around the world does not provide a direct link to ecology (Manh et al., 2014).

\section{Study area and model}

San Francisco estuary is the largest estuary on the US west coast. The estuary comprises San Francisco Bay and the inland Sacramento-San Joaquin Delta (Bay-Delta system), which together cover a total area of $2900 \mathrm{~km}^{2}$ with a mean water depth of $4.6 \mathrm{~m}$ (Jassby et al., 1993). The system has a complex geometry consisting of interconnected subembayments, channels, rivers, intertidal flats and marshes (Fig. 1). The Sacramento-San Joaquin Delta (Delta) is a collection of natural and man-made channel networks and leveed islands, where the Sacramento River and the San Joaquin River are the main tributaries followed by Mokelumne River (Delta Atlas, 1995). San Francisco Bay has four subembayments. The most landward is Suisun Bay followed by San Pablo Bay, central bay (connecting with the sea through Golden Gate) and, further southward, South Bay.

Tides propagate from the Golden Gate into the bay and most of the Delta up to the Sacramento River at Freeport (FPT) and the San Joaquin River near Vernalis (VNS) when river discharge is low. Suisun Bay experiences mixed diurnal and semidiurnal tide that ranges from about $0.6 \mathrm{~m}$ during the weakest neap tides to $1.8 \mathrm{~m}$ during the strongest spring tides. During high river discharge the 2 psu isohaline is lo- 
cated in San Pablo Bay while during low river discharge it can be landwards of Chipps Island (westernmost reach of the black rectangle; Fig. 1). The topography greatly influences the wind climate in the Bay-Delta system. Wind velocities are strongest during spring and summer with afternoon northwesterly gusts of about $9 \mathrm{~m} \mathrm{~s}^{-1}$ (Hayes et al., 1984).

San Francisco estuary collects $40 \%$ of the total Californian fresh water discharge. It has a Mediterranean climate, with $70 \%$ of rainfall concentrated between October and April (winter) decreasing until the driest month, September (summer) (Conomos et al., 1985). The orographic lift of the Pacific moist air linked to the winter storms and the snowmelt in early spring govern this wet (winter) and dry (summer) season variability. This system leads to a local hydrological water year (WY) defined as 1 October to 30 September, including a full wet season in $1 \mathrm{WY}$.

The Sacramento and San Joaquin rivers, together, account for $90 \%$ of the total fresh water discharge to the estuary (Kimmerer, 2004). The daily inflow to the Delta follows the rain and snowmelt seasonality, with average dry summer discharges of $50-150 \mathrm{~m}^{3} \mathrm{~s}^{-1}$ and wet spring/winter peak discharges of $800-2500 \mathrm{~m}^{3} \mathrm{~s}^{-1}$. The seasonality and geographic distribution of flows leads to several water issues related to agricultural use, habitat maintenance and water export. On a yearly average $300 \mathrm{~m}^{3} \mathrm{~s}^{-1}$ of water is pumped from the South Delta to southern California. The pumping rate is designed to keep the 2 psu (salinity) line landwards of Chipps Island avoiding salinity intrusion in the Delta, allowing for a $2 \mathrm{DH}$ modeling approach.

The hydrological cycle in the Bay-Delta determines the sediment input to the system, and thus biota behavior. McKee et al. (2006) and Ganju and Schoellhamer (2006) observed that a large volume of sediment passes through the Delta and arrives to the bay in pulses. They estimated that in 1 day approximately $10 \%$ of the total annual sediment volume could be delivered and in extremely wet years up to $40 \%$ of the annual total sediment volume can be delivered in 7 days. During wet months more than $90 \%$ of the total annual sediment inflow is supplied to the Delta.

The Delta's recent history is dominated by anthropogenic impacts. In the 1850s hydraulic mining started after placer mining in rivers became unproductive. Hydraulic mining remobilized a huge amount of sediment upstream of Sacramento. By the end of the nineteenth century the hydraulic mining was outlawed leaving approximately $1.1 \times 10^{9} \mathrm{~m}^{3}$ of remobilized sediment, which filled mud flats and marshes up to $1 \mathrm{~m}$ in the Delta and bay (Wright and Schoellhamer, 2004; Jaffe et al., 2007). At the same time mining prohibition ended, civil works such as dredging and construction of levees and dams started, reducing the sediment supply to the Delta (Delta Atlas, 1995; Whipple et al., 2012).

Typical SSC in the Delta ranges from 10 to $50 \mathrm{mg} \mathrm{L}^{-1}$, except during high river discharge when SSC can exceed $200 \mathrm{mg} \mathrm{L}^{-1}$ reaching values over $1000 \mathrm{mg} \mathrm{L}^{-1}$ (McKee et al., 2006; Wright and Schoellhamer, 2005). Sediment bud- get reflects the balance between storage, inflow and outflow of sediment in a system. Studies based on sediment inflow and outflow, estimated that about two-thirds of the sediment entering the system is deposited in the Delta (Schoellhamer et al., 2012; Wright and Schoellhamer, 2005). The remaining third is exported to the bay, and represents on average $50 \%$ of the total bay sediment supply (McKee et al., 2006), the other half comes from smaller watersheds around the bay (McKee et al., 2013).

Several studies have been carried out to determine sediment pathways and to estimate sediment budgets in the Delta area (Schoellhamer et al., 2012; Jaffe et al., 2007; Gilbert, 1917; McKee et al., 2006, 2013; Wright and Schoellhamer, 2005). These studies were based on data analysis and conceptual hindcast models. Although the region has a unique network of surveying stations, there are many channels without measuring stations. This might lead to incomplete system understanding and knowledge deficits for the development of water and ecosystem management plans. The monitoring stations are located in discrete points hampering spatial analysis. Also, the impact of future scenarios related to climate change (i.e., sea level rise and changing hydrographs) or different pumping strategies remains uncertain.

\subsection{Model description}

Structured grid models such as Delft3D and ROMS (Regional Oceanic Modeling System) have been widely used and accepted in estuarine hydrodynamics and morphodynamics modeling including studies of the San Francisco estuary (Ganju and Schoellhamer, 2009; Ganju et al., 2009; van der Wegen et al., 2011). In all of these studies the Delta was schematized as two long channels because the grid is not flexible, which would have allowed for efficient 2-D modeling of the rivers, channels and flooded island of the system together with the bay.

In cases with complex geometry, unstructured grids or a finite volume model is more suitable. There are three widely known unstructured grid models: (1) the TELEMAC-MASCARET (Hervouet, 2007), (2) the Unstructured Tidal, residual, intertidal mudflat model (UnTRIM) (Casulli and Walters, 2000; Bever and MacWilliams, 2013) and (3) Delft3D Flexible Mesh (D3D FM) (Kernkamp et al., 2010). The first two models are purely triangle based and are not directly coupled (yet) with sediment transport and/or water quality and ecology models.

The numerical model applied in this work is D3D FM. D3D FM allows for straightforward coupling of its hydrodynamic modules with a water quality model, Delft-WAQ (DELWAQ), which gives flexibility to couple with a habitat (ecological) model. D3D FM is a process-based unstructured grid model developed by Deltares (Deltares, 2014). It is a package for hydro- and morphodynamic simulation based on a finite volume approach solving shallow-water equations applying a Gaussian solver. The grid can be defined 


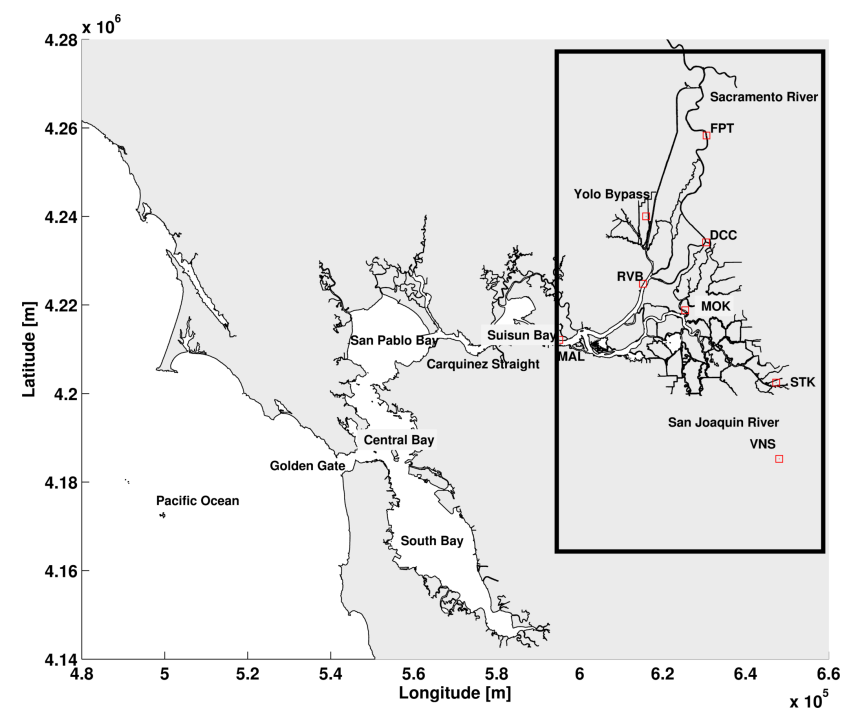

Figure 1. Location of the San Francisco Bay-Delta. The black rectangle highlights the Delta, and the red squares indicate measurement stations.

in terms of triangles, (curvilinear) quadrilaterals, pentagons and hexagons, or any combination of these shapes. Orthogonal quadrilaterals are the most computationally efficient cells and are used whenever the geometry allows. Kernkamp et al. (2010) and the D3D FM manual (Deltares, 2014) describe in detail the grid aspects and numerical solvers.

The bay area and river channels are defined by consecutive curvilinear grids (quadrilateral) of different resolution. Rivers discharging in the bay, and channel junctions are connected by triangles (Fig. 2). The average cell size ranges from $1200 \mathrm{~m} \times 1200 \mathrm{~m}$ in the coastal area, to $450 \mathrm{~m} \times 600 \mathrm{~m}$ in the bay area, down to $25 \times 25 \mathrm{~m}$ in Delta channels. In the Delta, each channel is represented by at least 3 cells in the across-channel direction (Fig. 2). The grid flexibility allows for including the entire Bay-Delta in a single grid containing 63844 cells of which about $80 \%$ are rectangles which keeps the computer run times at an acceptable level. It takes 6 real days to run 1 year of hydrodynamics simulation and $12 \mathrm{~h}$ to run the sediment module on an 8-core desktop computer. Besides the triangular grid orthogonality issues, using an entirely triangular grid for a 1-year simulation would increase run times from $\sim 72$ to $\sim 192 \mathrm{~h}$.

We assume that the main flow dynamics in the Delta is 2-D, which does not account for vertical stratification. The Delta does not experience salt-fresh water interactions due to the pumping operations and we assume that temperature differences between the top and bottom of the water column do not govern flow characteristics. D3D FM generates hydrodynamic output for off-line coupling with water quality model DELWAQ (Deltares, 2014). Off-line coupling enables faster calibration and sensitivity analysis. D3D FM generates time series of the following variables: cell link area; bound- ary definition; water flow through cell link; pointers that give information about neighbors' cells; cell surface area; cell volume; and shear stress file, which is parameterized in D3D FM using Manning's coefficient. Given a network of water levels and flow velocities (varying over time) DELWAQ can solve the advection-diffusion-reaction equation for a wide range of substances including fine sediment, the focus of this study. DELWAQ solves sediment source and sink terms by applying the Krone-Parteniades formulation for cohesive sediment transport (Krone, 1962; Ariathurai and Arulanandan, 1978) (Eqs. 1 and 2).

$D=w_{\mathrm{s}} \cdot c \cdot\left(1-\frac{\tau_{\mathrm{b}}}{\tau_{\mathrm{d}}}\right)$, which is approximated as

$$
D=w_{\mathrm{s}} \cdot c,
$$

where $D$ is the deposition flux of suspended matter $\left(\mathrm{mg} \mathrm{m} \mathrm{m}^{-2} \mathrm{~s}^{-1}\right), w_{\mathrm{s}}$ is the settling velocity of suspended matter $\left(\mathrm{m} \mathrm{s}^{-1}\right), c$ is the concentration of suspended matter near the bed $\left(\mathrm{mg} \mathrm{m}^{-3}\right), \tau_{\mathrm{b}}$ is bottom shear stress $(\mathrm{Pa})$ and $\tau_{\mathrm{d}}$ is the critical shear stress for deposition (Pa). The approximation is made assuming, like Winterwerp et al. (2006), that deposition takes place regardless of the prevailing bed shear stress. $\tau_{\mathrm{d}}$ is thus considered much larger than $\tau_{\mathrm{b}}$ and the second term in parentheses of Eq. (1) is small and can be neglected.

$E=M \cdot\left(\tau_{\mathrm{b}} / \tau_{\mathrm{e}}-1\right)$ for $\tau_{\mathrm{b}}>\tau_{\mathrm{e}}$

where $E$ is the erosion rate $\left(\mathrm{mg} \mathrm{m}^{-2} \mathrm{~s}^{-1}\right), M$ is the first-order erosion rate $\left(\mathrm{mg} \mathrm{m}^{-2} \mathrm{~s}^{-1}\right)$, and $\tau_{\mathrm{e}}$ is the critical shear stress for erosion $(\mathrm{Pa})$.

\subsection{Initial and boundary conditions}

The Bay-Delta is a well-measured system; therefore, all the input data to the model are in situ data. Initial bathymetry has $10 \mathrm{~m}$ grid resolution, which is based on an earlier grid (Foxgrover et al., 2012, http://sfbay.wr.usgs.gov/ sediment/delta/), modified to include new data by Wang and Ateljevich (http://baydeltaoffice.water.ca.gov/modeling/ deltamodeling/modelingdata/DEM.cfm) and further refined. The bathymetry is based on different data sources including bathymetric soundings and lidar data. The hydrodynamic model includes real wind, which results from the model described by Ludwig and Sinton (2000). The wind model spatially interpolates hourly data from more than 30 meteorological stations into regular $1 \mathrm{~km}$ grid cells. Levees are included in the model and temporary barriers are inserted to mimic a typical operating schedule as determined by the California Department of Water Resources (http://baydeltaoffice.water. ca.gov/sdb/tbp/web_pg/tempbsch.cfm).

The hydrodynamic model has been calibrated for the entire Bay-Delta system (see Appendix A and http://www. d3d-baydelta.org/). Initial SSC was set at $0 \mathrm{mg} \mathrm{L}^{-1}$ over the entire domain because the model is initiated during dry period when SSC is low and the initial condition rapidly dissipates. The initial bottom sediment is mud at places shallower 


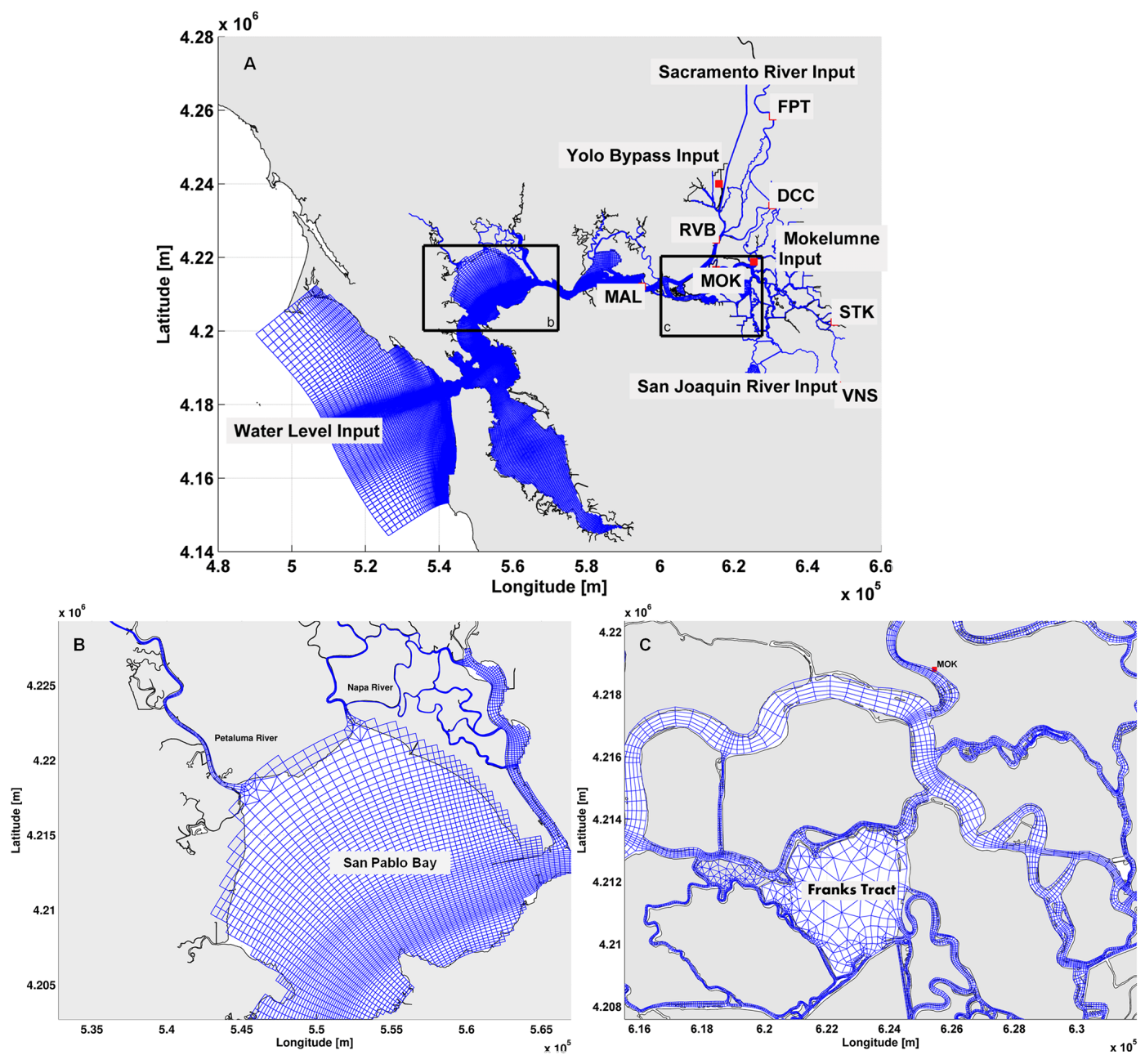

Figure 2. Numerical mesh for the D3D FM model. Red dots indicate the calibration stations (http://san-francisco-bay-delta-model. unesco-ihe.org/). Detailed box of the computational grid: (b) San Pablo Bay connecting to the Petaluma and Napa rivers, (c) delta channels and Franks Tract.

than $5 \mathrm{~m}$ b.m.s.l. (below mean sea level) including intertidal mud flats, and sand at places deeper than $5 \mathrm{mb}$.m.s.l., which are primarily the channel regions. This implies that the main Delta channels such as, the Sacramento, San Joaquin and Mokelumne are defined as sandy with a few mud patches. DELWAQ does not compute morphological changes or bed load transport.

In this study we applied five open boundaries. Water levels at the seaward boundary are based on hourly measurements from the Point Reyes station (tidesandcurrents.noaa. gov/). The other four landward boundaries are river discharge boundaries at the Sacramento River (Freeport), Yolo Bypass (YOLO) (upstream water divergence from Sacramento River), San Joaquin River and Mokelumne River. Studies show that Sacramento River accounts for $85 \%$ of the total sediment inflow to the Delta, while the San Joaquin River accounts for $13 \%$ (Wright and Schoellhamer, 2005), so it is reasonable to apply two sediment discharge boundaries at the
Sacramento and San Joaquin rivers. All river boundaries have unidirectional flow and are landward of tidal influence.

The river water flow hourly input data at the FPT, the VNS and YOLO were obtained from the California Data Exchange Center website (cdec.water.ca.gov/) (Fig. 3). The sediment input data, for both input stations FPT and VNS, and calibration stations S Mokelumne R (SMR), N Mokelumne R (NMR), Rio Vista (RVB), Mokelumne (MOK), Little Potato slough (LPS), Middle River (MDM), Stockton (STK) and Mallard Island (MAL) (Fig. 3), were obtained by personal communication from USGS Sacramento; these data are part of a monitoring program (http://sfbay.wr.usgs.gov).

Since 1998, USGS has continuous measuring stations for sediment concentration which is derived from backscatter sensors (OBS) measurements every $15 \mathrm{~min}$, and are calibrated approximately monthly with bottle samples (Wright and Schoellhamer, 2005). This type of sensor converts scattered light from the particles to photocurrent, which is pro- 


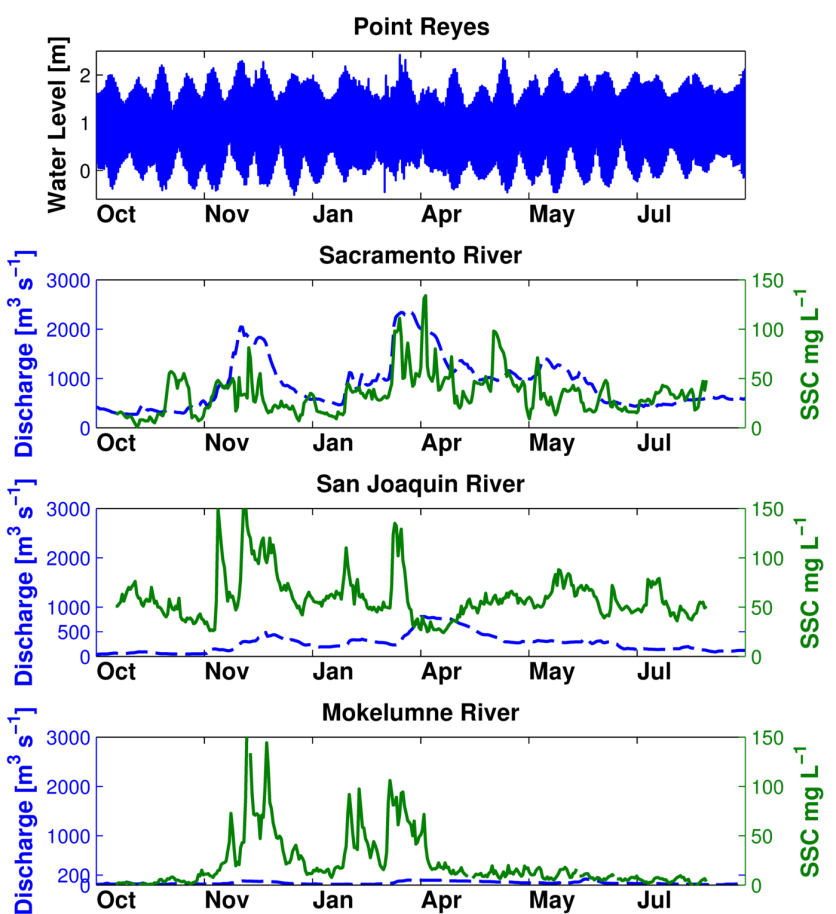

Figure 3. Input boundary conditions. The top panel is water level at Point Reyes. The lower three panels show discharge in a dashed blue line and SSC in a solid green line for Sacramento River at FPT, San Joaquin River at VNS and Mokelumne River at Woodbridge, respectively.

portional to SSC. To define the rating curve it is necessary to sample water, filter it and weigh the filter. However, in some locations the cloud of points when correlating photocurrent and filtered weight shows a large scatter. Large scatter leads to errors in converting photocurrent to SSC. The causes for errors include variation in particle size, particle desegregation (cohesiveness, flocculation, organic-rich estuarine mud), particle shape effects and sediment-concentration effects (Kineke and Sternberg, 1992; Downing, 2006; Sutherland et al., 2000; Gibbs and Wolanski, 1992; Ludwig and Hanes, 1990). Wright and Schoellhamer (2005) showed that for the Sacramento-San Joaquin delta these errors can sum up to $39 \%$, when calculating sediment fluxes through Rio Vista.

In this work we modeled the 2011 WY - 1 October 2010 to 30 September 2011. First, we ran D3D FM for this year to calculate water level, velocities, cell volume and shear stresses. Then, the 1 year hydrodynamic results were imported in DELWAQ which calculated SSC levels.

The SSC model results are compared to in situ measured SSC data. The calibration process assesses the sensitivity of sediment characteristics such as fall velocity (ws), critical shear stress $\left(\tau_{\mathrm{cr}}\right)$ and erosion coefficient $(M)$. The model outputs are the spatial and temporal distribution of SSC (turbid- ity), yearly sediment budget for different Delta regions, and the sediment export to the bay.

\section{Results}

Our focus is to represent realistic SSC levels capturing the peaks, timing and duration, and to develop a sediment budget to assess sediment trapping in the Delta (Fig. 1, highlighted by the black rectangle). Throughout the following sections the results are analyzed in terms of tide-averaged quantities by filtering data and model results to frequencies lower than 2 days. We applied a Butterworth filter with a cutoff frequency of $1 / 30 \mathrm{~h}^{-1}$ as presented in Ganju and Schoellhamer (2006).

\subsection{Calibration}

The results shown below are the derived from an extensive calibration process where the different sediment fractions parameters (ws, $\tau_{\mathrm{cr}}$ and $M$ ) were tested. The first attempt applied multiple fraction settings presented in previous works (van der Wegen et al., 2011; Ganju and Schoellhamer, 2009). However, tests with a single mud fraction proved to be consistent with the data, representative of the sediment budget, and allow for a simpler model setting and better understanding of the SSC dynamics. In addition, with a single fraction it was possible to reproduce more than $90 \%$ of the sediment budget for the Delta when compared with the sediment budget derived from in situ data.

The best fit of the calibration process ( $\mathrm{uRMS}=1$ and skill $=0.8$ ) for the entire domain was obtained in the standard run, which has ws of $0.25 \mathrm{~mm} \mathrm{~s}^{-1}, \tau_{\mathrm{cr}}$ erosion of $0.25 \mathrm{~Pa}$ and $M$ of $10^{-4} \mathrm{~kg} \mathrm{~m}^{-2} \mathrm{~s}^{-1}$. The initial bed sediment availability is defined by one mud (shoals) and one sand (channels) fraction. The analysis present below is based in the standard run, and the sensitivity analysis varies the 3 parameters using the standard run as a mid-point.

\subsection{Suspended sediment dynamics (water year 2011)}

The 2011 WY simulation reproduces the SSC seasonal variation in the main Delta regions such as the north (Sacramento River) represented by Rio Vista station (RVB), the south (San Joaquin River) represented by Stockton (STK), central-east delta represented by Mokelumne station (MOK) and delta output represented by Mallard Island (MAL) (Fig. 4).

All stations clearly reproduce SSC peaks during high river flow from November to July, and lower concentrations during the remainder of the year (apart from MAL during the JulyAugust period). The good representation of the peak timing indicates that the main Delta discharge event is reproduced by the model as well as the periods of delta clearance. These two periods are critical for ecological models, and a good representation generates robust input to ecological models. 


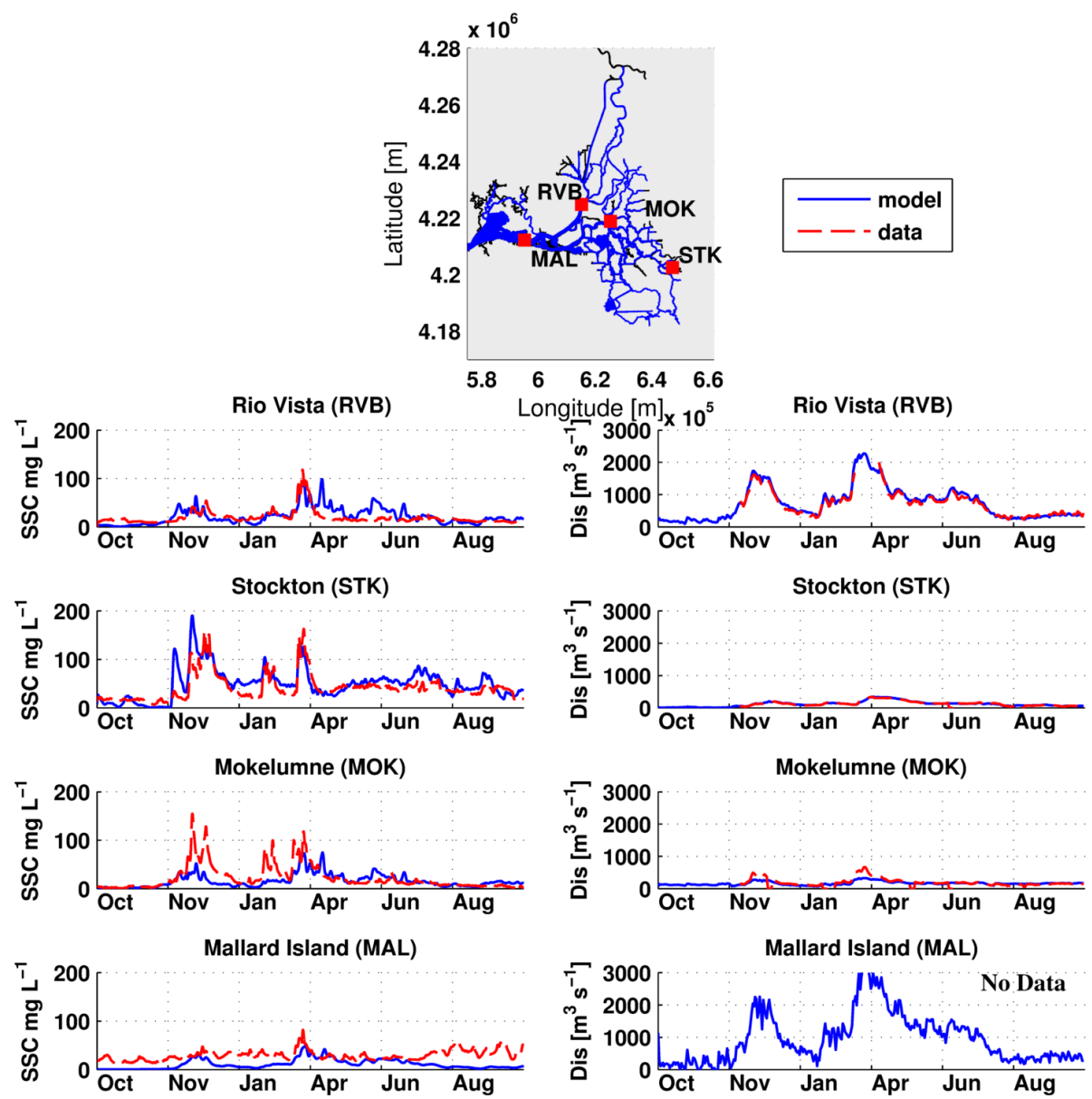

Figure 4. Calibration station locations (top panel) and comparison of model outputs and measured data. Left panels show SSC calibration and right panels the show discharge. Data are dashed red lines and model results are solid blue lines. Note that in the discharge plots of RVB and STK the data line is behind the model line.

The differences found between the model and data are further discussed in Appendix B.

\subsection{Sensitivity analysis}

\section{Sediment fraction analysis}

We considered one fraction for simplicity and because it reproduces more than $90 \%$ of the sediment budget throughout the Delta as well as the seasonal variability of SSC levels. Although more mud fractions considerably increase running time, several tests with multiple fractions were done to explore possibilities for improving the model results.

Including heavier fractions changes the peaks timing and also lowers the SSC curve. Comparing the standard run (ws $=0.25 \mathrm{~mm} \mathrm{~s}^{-1}, T=0.25 \mathrm{~Pa}, M=10^{-4} \mathrm{~kg} \mathrm{~m}^{-2} \mathrm{~s}^{-1}$ and bottom composition with mud available shallower than $5 \mathrm{~m}$ ) to another run using $15 \%$ of a heavier fraction $\left(\mathrm{ws}=1.5 \mathrm{~mm} \mathrm{~s}^{-1}\right.$ ) and $30 \%$ of a lighter fraction (ws $=0.15 \mathrm{~mm} \mathrm{~s}^{-1}$ ), showed that the peak magnitudes were underestimated but the first peak timing is closer to the data and the spurious peak mid-May is lower.

To be able to find a single best parameter setting a sensitivity analysis was done varying the main parameters in the Krone-Parteniades formulation (Table 1). Regarding sediment flux, these tests show that RVB and MAL are more sensitive to parameter change than STK (Fig. 5). The model results are most sensitive to the critical shear stress for erosion and least sensitive to the erosion coefficient. Analyzing the time series, one concludes that in stations where the fluxes are higher, the change in critical shear stress is less important, since during most of the time the shear stress is already higher than any given critical shear stress.

We quantify error using two metrics, the unbiased root mean square error (uRMSE; Fig. 6) and skill (skill; Fig. 6) (Bever and MacWilliams, 2013). The uRMSE indicates the variability of the model relative to the data and is zero when the model and data have equal variability. 
Table 1. Parameters set of sensitivity analysis.

\begin{tabular}{llll}
\hline \multicolumn{1}{c}{ Parameters } & Minimum & Maximum \\
\hline Standard & & $w=0.25 ; \tau=0.25 ; M=1 \times 10^{-4}$ \\
Fall velocity ws & $\left(\mathrm{mm} \mathrm{s}^{-1}\right)$ & 0.15 & 0.38 \\
Critical shear stress $\tau_{\mathrm{cr}}$ & $(\mathrm{Pa})$ & 0.125 & 0.5 \\
Erosion coefficient $M$ & $\left(\mathrm{~kg} \mathrm{~m}^{2} \mathrm{~s}^{-1}\right)$ & $2.5 \times 10^{-5}$ & $1 \times 10^{-2}$ \\
\hline
\end{tabular}

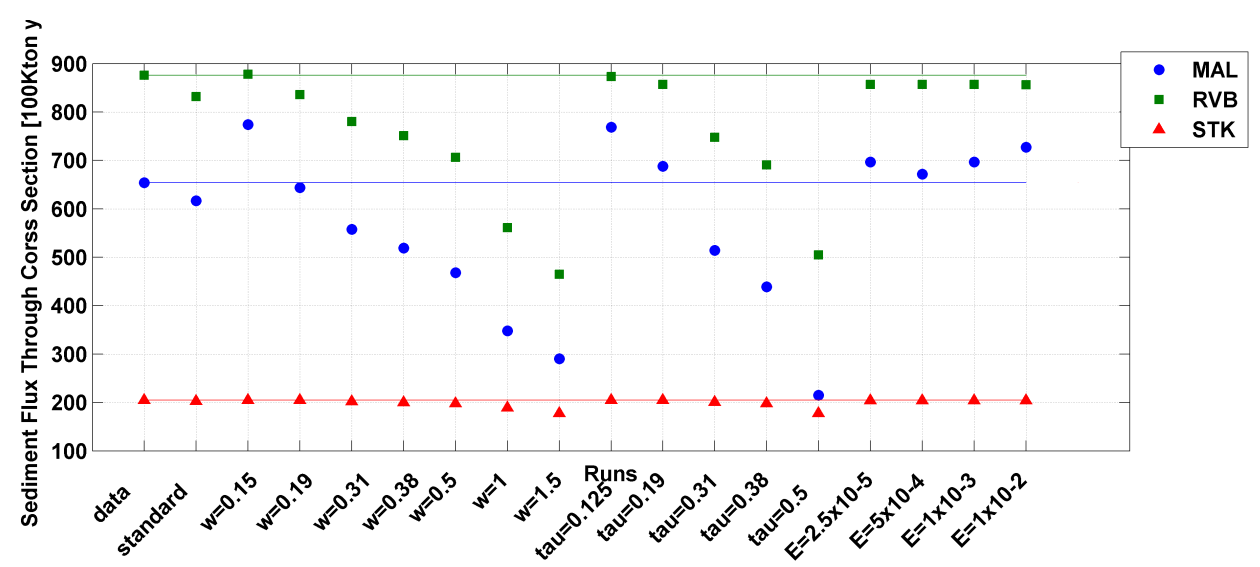

Figure 5. Sensitivity analysis for sediment flux at RVB on the Sacramento River (green squares), at STK on the San Joaquin River (red triangles) and at MAL where the Delta meets the Bay (blue circles). The colored lines indicate the data values.

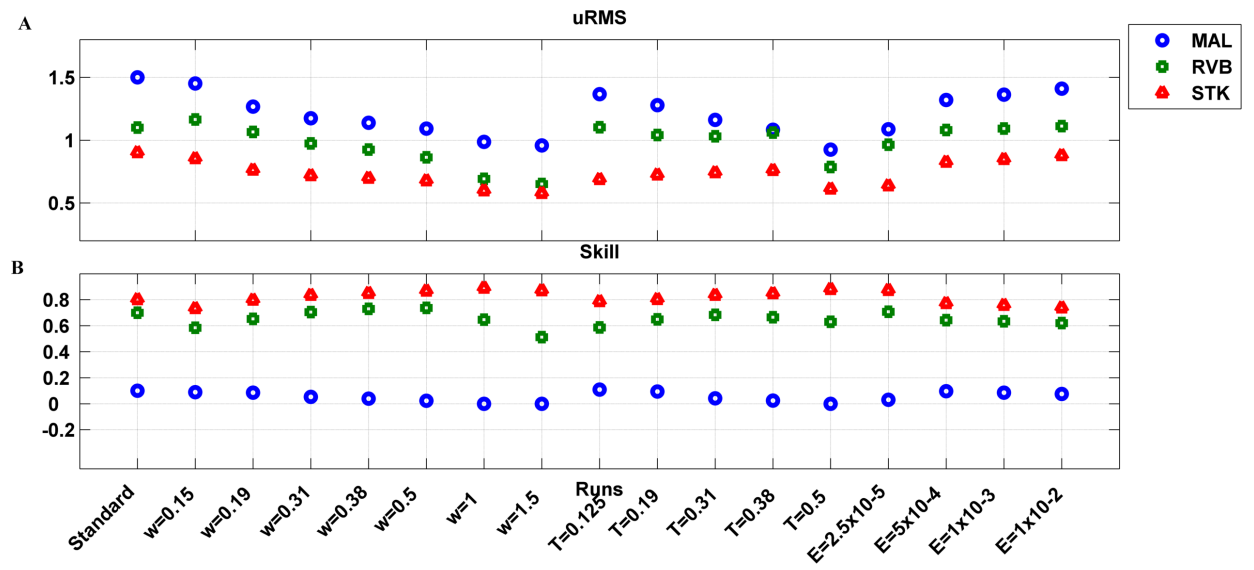

Figure 6. Statistical metrics for sensitivity runs. (a) Unbiased root mean square and (b) skill. On the $x$ axis are the different runs. Colored symbols are stations RVB (green square), STK (red triangle) and MAL (blue circle).

$\mathrm{uRMSE}=\left(\frac{1}{N} \sum_{i=1}^{N}\left[\left(X_{\mathrm{m}_{i}}-\bar{X}_{\mathrm{m}}\right)\left(X_{\mathrm{O}_{i}}-\bar{X}_{\mathrm{O}}\right)\right]^{2}\right)^{0.5}$,

where $N$ is the time series size, $X$ is the variable to be compared, in this case SSC, and $\bar{X}$ is the time-averaged value. Subscript " $m$ " and "O" represent modeled and observed values, respectively.

Skill is a single quantitative metric for model performance (Willmott, 1981). When skill equals 1 the model perfectly reproduces the data. The two metrics where evaluated at RVB,
STK and MAL, representing respectively Sacramento River, San Joaquin River and delta output.

$$
\begin{aligned}
\text { Skill }= & 1-\left[\sum_{i=1}^{N}\left|X_{\mathrm{m}_{i}}-\bar{X}_{\mathrm{O}_{i}}\right|^{2}\right] / \\
& {\left[\sum_{i=1}^{N}\left(\left|X_{\mathrm{m}_{i}}-\overline{X_{\mathrm{O}}}\right|+\left|X_{\mathrm{O}_{i}}-\overline{X_{\mathrm{O}}}\right|\right)^{2}\right] }
\end{aligned}
$$

The choice of the standard run analyzed throughout the paper comes from this analysis as well as the budget analysis. We 
note that both uRMSE and skill varies up to $50 \%$ over the different runs.

\subsection{Initial bottom composition}

To study the importance of initial bottom sediment availability we considered two cases: one excluding sediment (no sediment available at the bed) and the other with mud at places shallower than $5 \mathrm{~m}$ b.m.s.l., the same setting as the standard run.

We did some tests varying the $5 \mathrm{~m}$ threshold. From 3 to $10 \mathrm{~m}$ the final results are all similar. However, allowing mud availability in the channels deeper than $10 \mathrm{~m}$ starts to affect the SSC levels. Time series of SSC comparing the two cases show that bottom composition has virtually no influence on SSC after the first couple of days. This result also applies for different mud fractions availability and suggests it may be possible to accurately model less-measured estuaries where virtually no bottom sediment data are available.

Another test shows that it is better to initialize the model with no sediment at the bed than with mud available in the entire domain. Initializing the channels with loose mud generates unrealistically high SSC levels through the years, which can take up to 5 years to be reworked.

\section{Discussion}

In the previous section we presented the model calibration, a normal practice in the modeling process. In this section we discuss the new insights that were derived from the model results. Although these insights are specific to the San Francisco Bay-Delta system, the same approach can be applied to other estuaries and deltas. The model produces detailed sediment dynamics and the main paths in which sediment is transported in the Delta. Sediment flux calculations define the sediment dynamics, while gradients in sediment describe the sediment distribution and deposition pattern in the Delta. We also discuss daily and seasonal variation of turbidity levels.

\subsection{Spatial sediment distribution}

We start the analysis by exploring the general Delta behavior. During dry periods SSC in the entire Delta is low $\left(<20 \mathrm{mg} \mathrm{L}^{-1}\right)$ and the Delta water is relatively clear. The current model results confirm that the Sacramento River is the main sediment supplier into the Delta (Wright and Schoellhamer, 2004; Schoellhamer et al., 2012). The Sacramento River peak flow fills the north and partially fills the central/east delta with sediment. However, the rest of the Delta has quite low levels $\left(\sim 20 \mathrm{mg} \mathrm{L}^{-1}\right)$ of SSC all year long. Passing VNS, the San Joaquin River main branch flows to the east; however, the SSC peak does not reach much further than STK. The west branch goes toward the water pumping stations where the sediment is pumped out of the system.
This behavior results in very low SSC in the south Delta (Old River and Franks Tract) region, which are deposition areas.

Three Mile slough (TMS) and the delta cross channel (DCC) connect the Sacramento River with the central and eastern Delta. Model results show that together they carry $60 \mathrm{Kt}$ per year of sediment southward. DCC operation controls SSC levels in the eastern/central Delta to a large extent. To show the importance of the DCC we run the model twice, once with the DCC always open and once always closed. When the DCC is open, high SSC Sacramento River water $\left(\sim 150 \mathrm{mg} \mathrm{L}^{-1}\right)$ flows towards the Mokelumne River and eastern delta increasing the overall SSC in the area. When it is closed SSC levels in the central and eastern Delta are about $30 \mathrm{mg} \mathrm{L}^{-1}$ lower than in the previous case (Fig. 7). The effect of opening the DCC can be observed in the SSC level at the San Joaquin River from the MOK station seawards. In the Sacramento River, the opening decreases SSC levels, by about $10 \mathrm{mg} \mathrm{L}^{-1}$ and affects the river SSC all the way to Mallard Island (Fig. 7).

During peak river discharge, Sacramento River sediment reaches Mallard Island in approximately 3 days, Carquinez straight in 5 days and the Golden Gate Bridge in approximately 10 days. This timing is proportional to river discharge. However, from Mallard Island seawards this estimate is inexact due to the 2-D approximation. San Joaquin River sediment remains largely trapped in the southern delta. The flooded islands, breached levees like Franks Tract, present a different behavior. During the entire year the SSC levels are below $15 \mathrm{mg} \mathrm{L}^{-1}$ - the river peak discharge signal does not affect them.

Sediment flux is a useful tool for a quantitative and qualitative analysis of the sediment pathways and its derivative gives sedimentation/erosion patterns. Sediment flux is defined by the product of water velocity $(U)$ times cross sectional area $(A)$ times $\operatorname{SSC}(C)($ Eq. 5).

$F_{\mathrm{sed}}=U \cdot A \cdot C$

The yearly sediment flux through FPT from model results is $1132 \mathrm{Ktyr}^{-1}$ (thousand metric tons per year) and $1096 \mathrm{Kt} \mathrm{yr}^{-1}$ from data. Farther seaward on the Sacramento River at RVB the sediment flux is $832 \mathrm{Kt} \mathrm{yr}^{-1}\left(994 \mathrm{Kt} \mathrm{yr}^{-1}\right.$, data). Sediment flux at MAL is $617 \mathrm{Kt} \mathrm{yr}^{-1}\left(654 \mathrm{Kt} \mathrm{yr}^{-1}\right)$ (Fig. 8). We calculate that $30 \mathrm{Kt} \mathrm{yr}^{-1}$ of Sacramento River sediment flows to the eastern Delta through the DCC, and $30 \mathrm{Kt} \mathrm{yr}^{-1}$ through TMS and $20 \mathrm{Kt} \mathrm{yr}^{-1}$ from Georgina slough. The San Joaquin River carries $490 \mathrm{Kt} \mathrm{yr}^{-1}$ (498) through VNS, and at STK $205 \mathrm{Kt} \mathrm{yr}^{-1}\left(190 \mathrm{Kt} \mathrm{yr}^{-1}\right)$. An estimated $100 \mathrm{Kt} \mathrm{yr}^{-1}$ is exported through pumping. To close the system in central delta, the flux through Jersey point (JPT) is $126 \mathrm{Kt} \mathrm{yr}^{-1}$ (no data) and at the Dutch cross channel (DCH) approximately zero (no data) (Fig. 8).

Seaward from MAL considerable salt-freshwater stratification takes place in the water column. These 3-D effects are not captured by our 2DH approach and model results in this 


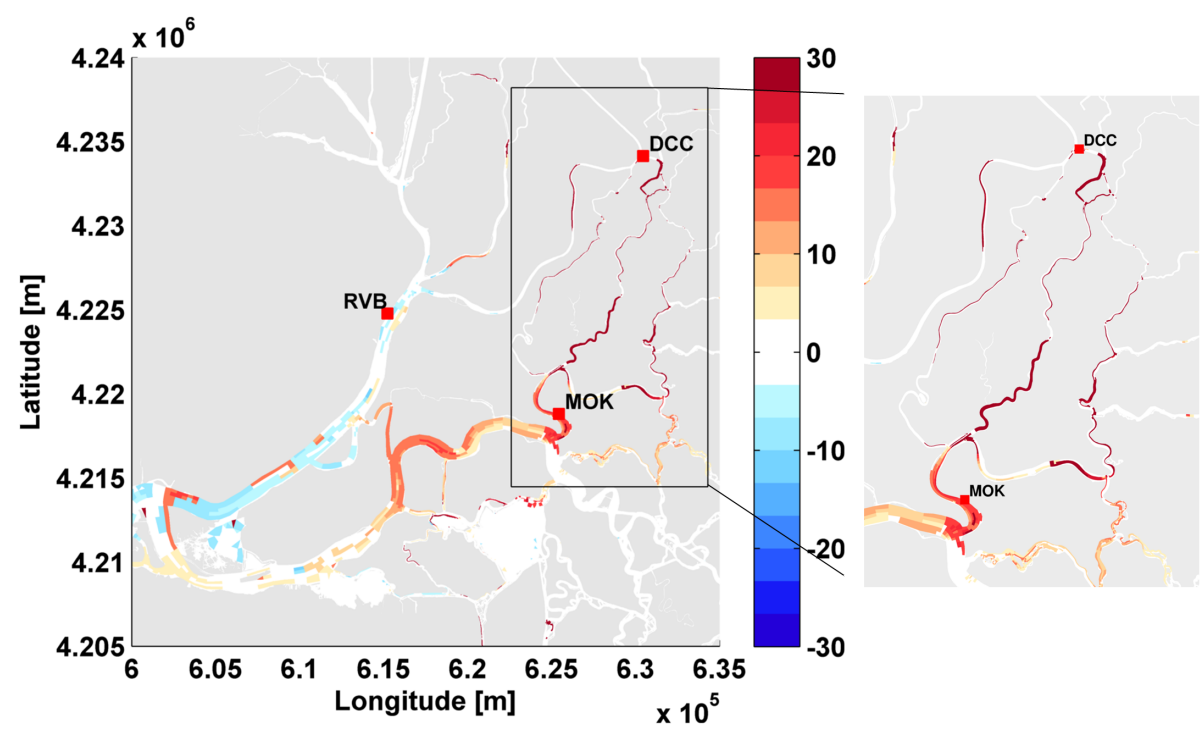

Figure 7. Anomaly of a SSC $\left(\mathrm{mg} \mathrm{L}^{-1}\right)$ snapshot between runs with open-closed DCC. This pattern is representative in time as well. The right panel is a detailed box between the DCC and MOK (black rectangle). Red shades represent regions where the SSC level is higher in the open than the close scenario, the blue shades where it was lower.
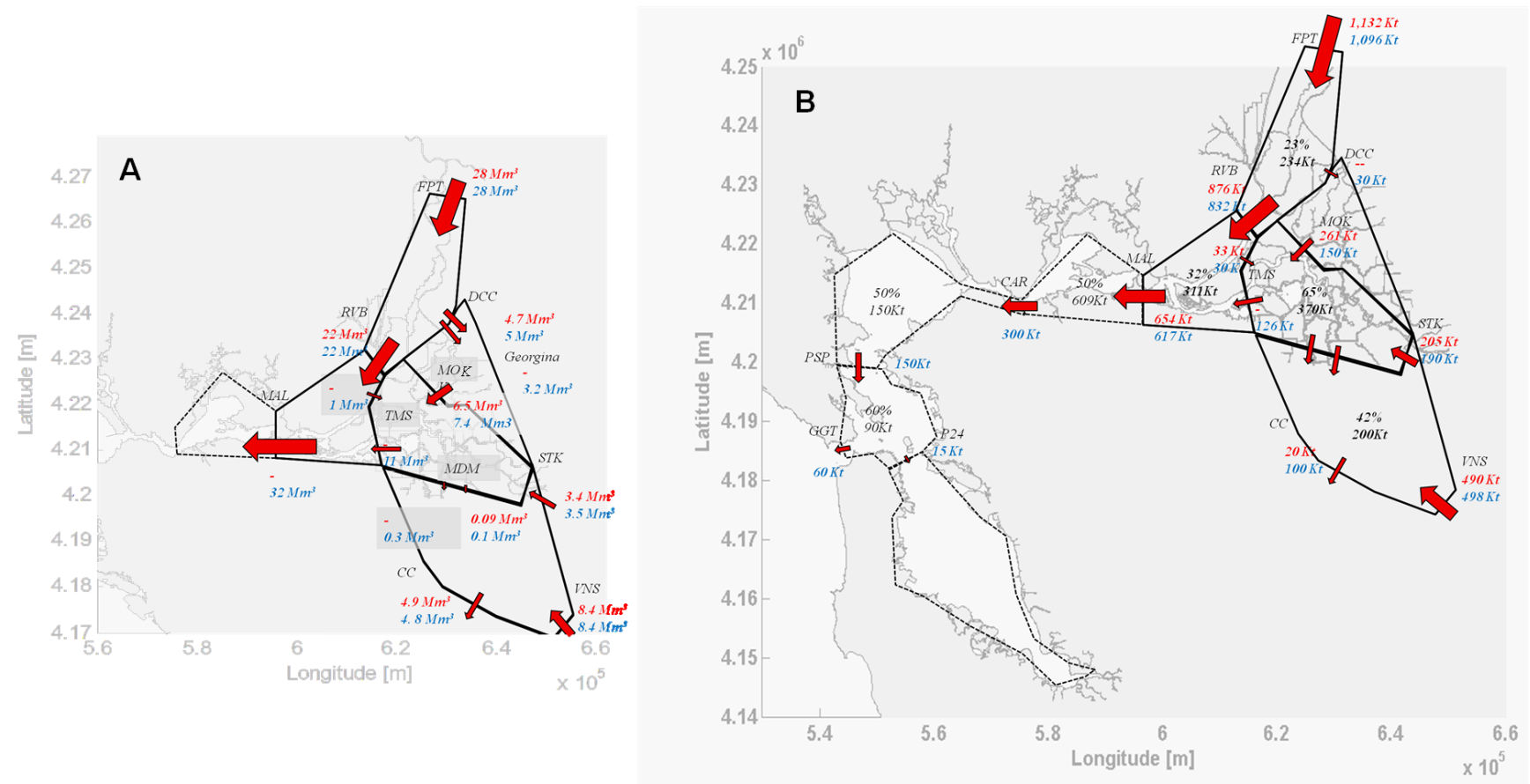

Figure 8. Water discharge (a) and sediment flux (b) pathway models. The arrows represent the water (a) and sediment (b) fluxes through the cross sections. Area of the arrow is proportional to the flux. Fluxes from data are in red and from the model are in blue. Inside each polygon are the trapping efficiency and deposition volume for the area. The bay portion is dashed because the model is 2-D and 3-D processes occur in that region.

region are inaccurate. Therefore, Fig. 8 shows preliminary sediment flux to the bay by a dashed line.

\subsection{Sediment budget}

From the previous section one can see that more sediment enters $\left(\sim 1600 \mathrm{Kt} \mathrm{yr}^{-1}\right)$ than leaves $\left(\sim 600 \mathrm{Kt} \mathrm{yr}^{-1}\right)$ the Delta; the difference between inflow and outflow deposits in the 
Delta. Jaffe et al. (2007) developed a box model based on bathymetry data to define the sediment budget of the Delta and bay in order to define sediment availability for ecology purposes. The model results agree with data estimations that about two-thirds of the sediment input is retained in the Delta (Schoellhamer et al., 2012; Wright and Schoellhamer, 2005), and retention is consistent throughout the years (Cappiella et al., 1999; Jaffe et al., 1998; Wright and Schoellhamer, 2004). Because the D3D FM model provides a detailed description of the sediment pathways, it is possible to further understand and describe the sediment budget in Delta sub-regions (north, central and south) and to compare model results to data when available (M. King, personal communication, 2012).

Besides the overall spatial trend, different parts of the Delta have different trapping efficiencies: the northern Delta (the least efficient) traps $\sim 23 \%$; central/eastern Delta traps $32 \%$; central/western $65 \%$; and the most efficient region, the southern Delta, traps $67 \%$ of the sediment input. The highest trapping efficient regions are where islands inundated through levee breaching (Wright and Schoellhamer, 2005).

Of the total Sacramento River sediment input $40 \%$ stays in the northern Delta and about $40 \%$ is exported to the Bay. The remaining $20 \%$ deposits in the central/eastern delta and only $2 \%$ travels all the way to the south Delta. About $70 \%$ of San Joaquin sediment deposits in the southern Delta, $10 \%$ goes to the central Delta, $15 \%$ is exported via Clifton court pumping facilities and $5 \%$ is exported to the bay. This transport is reflected in the bottom composition of the Delta. Sacramento River sediment dominates the northern and central Delta and San Joaquin River sediment dominates the southern delta bottom composition (Fig. 9).

It is enlightening to divide the sediment budget analysis into wet and the dry seasons, since the delta has different dynamics for each season. Water year 2011 was a wet year, with the wet season lasting from mid-January until the end of May. During the wet period $60 \%$ of the yearly sediment input budget entered the delta through FPT and VNS and 70\% of the yearly budget was exported through MAL. In the wet season the high river water discharges and SSC pulses flush the entire delta with sediment. In this season high SSC gradients are observed in the plume fronts leading to rapid changes in habitat conditions for many species. After the front the high SSC level can last for more than 1 month, indicating changing in habitat conditions

During the dry season the delta experiences lower river discharges and SSC levels resulting in lower sediment transport rates. In the dry season SSC levels do not have peaks and are more uniform. During the dry season the water is clear and the advective flux is lower, which will be discussed in the next section.

\subsection{Sediment flux analysis}

SSC peaks at FPT can be tracked down the estuary. At the RVB station the SSC peak follows the same dynamic as that

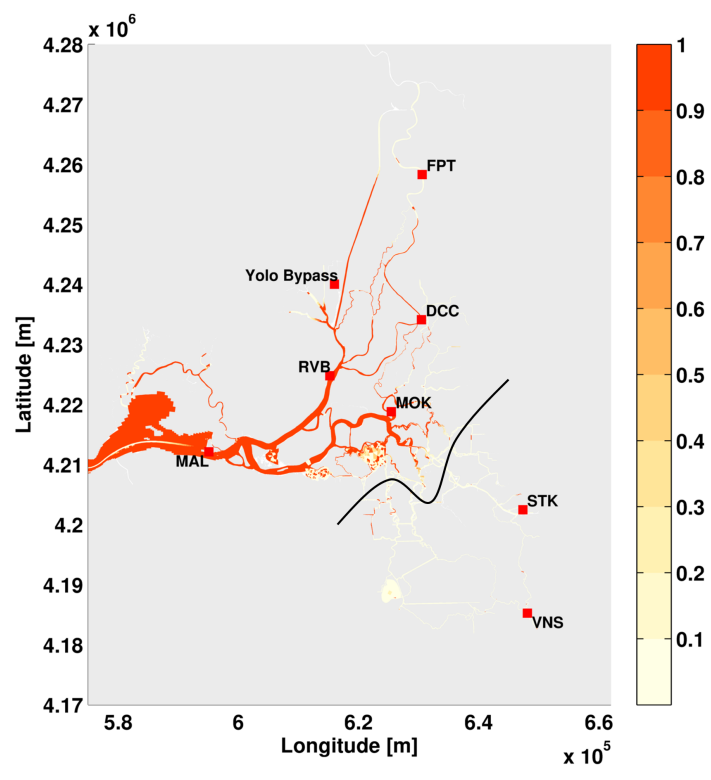

Figure 9. Sediment bottom composition after 1 year, starting with no bed sediment available. Red shades indicate dominance of Sacramento River sediments and white shades dominance of San Joaquin River sediments. The black line highlights where this separation occurs.

observed at FPT; however, this behavior does not apply for the entire delta. Schoellhamer and Wright (2005) observed that the river signal is attenuated through the estuary. This attenuation can be understood by analyzing changes in the dominant sediment flux component.

Dyer (1974) decomposed the tidally averaged fluxes in three main components: tidal mean, the advective term; tidal fluctuation, the dispersive term; and the Stokes drift. This decomposition was possible considering that the measured valued is the sum of a tidally mean component $[x]$, and a fluctuating component $x^{\prime}$; therefore, $x=[x]+x^{\prime}$, substituting in Eq. (5) and simplifying the small contribution terms, three main terms remain (Eq. 6). The first term of Eq. (6) is the advective term, the river sediment flux calculated as the product of the mean discharge, area and concentration; the second term is the dispersive sediment flux that accounts for tidal pumping of sediment. The first two terms account for more than $95 \%$ of the sediment flux. The remaining sediment flux is from the third term, Stokes drift, which is the transport due to a variation in the cross sectional area.

$\left.[F]=[U][A][C]+\left[U^{\prime}[A] C^{\prime}\right]\right]+\left[\left[U^{\prime} A^{\prime}[C]\right]\right]$

The model allows for a detailed temporal and spatial analysis of the three flux components. The temporal analysis is done for the whole year and for the wet and dry seasons separately. For the spatial analysis, we defined four stations for each river where the first station is dominated by the river flux and the last experiences a mix of tidal and river fluxes. The stations follow the Sacramento River, starting with FPT, 

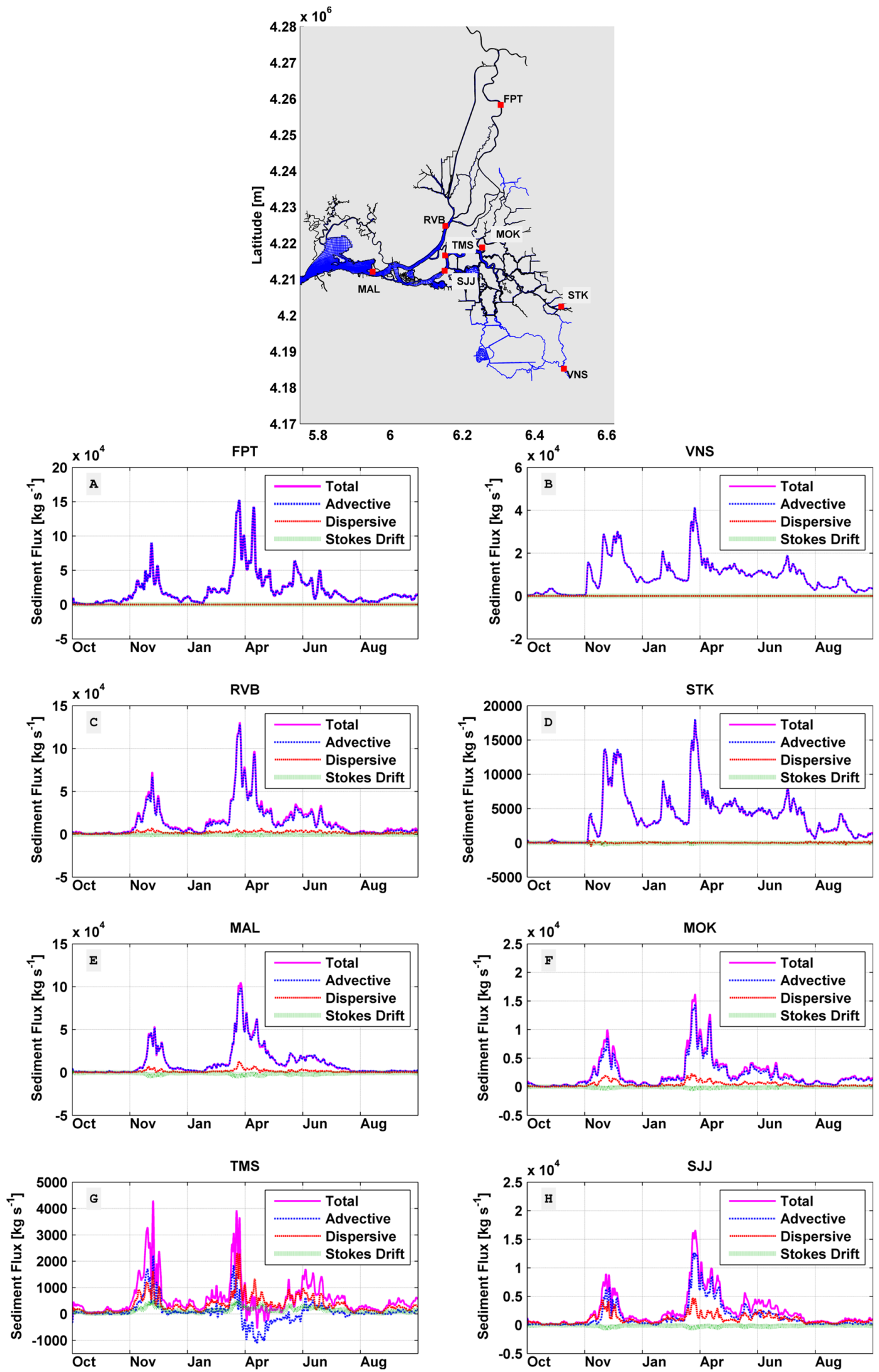

Figure 10. Sediment flux calculations for several stations within the Delta. (a), (c), (e) and (g) show the sediment flux change following the Sacramento branch and (b), (d), (f) and (h) following the San Joaquin branch. The total flux is represented in magenta, advective flux in blue, dispersive flux in red and Stokes drift in green. The total and advective sediment fluxes are the same at FPT and VNS. Positive is seaward. 


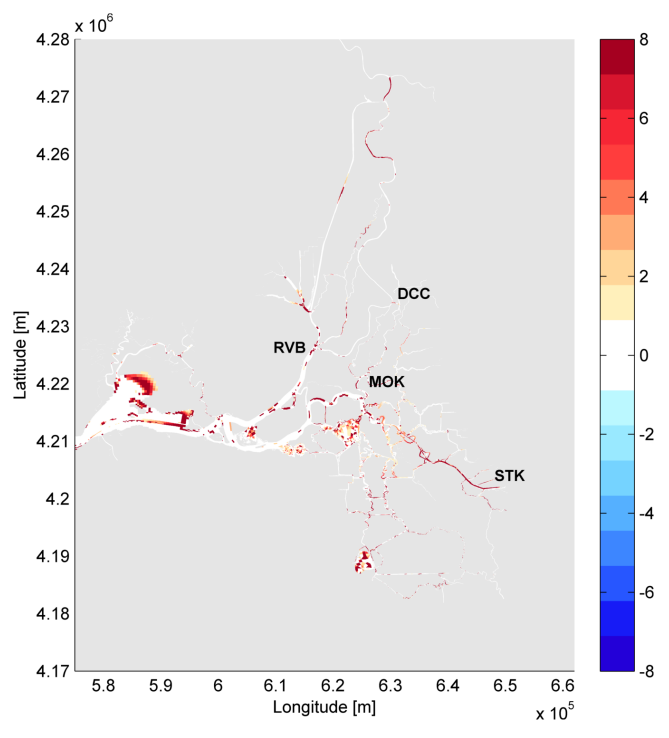

Figure 11. Modeled deposition in millimeters for 1 year period.

followed by RVB down to Mallard Island where the Delta joins the bay. Stations following the San Joaquin River are VNS, STK and MOK. Three Mile Slough and San Joaquin Junction (SJJ) represent the Delta smaller channels.

Sacramento River at FPT, the most landward station, experiences no tidal influence so the flux is purely advective. At RVB, which is seaward, there are tidal fluctuations and the dispersive flux is responsible for $22 \%$ of the total flux; however, no Stokes drift flux is present (Fig. 10). In contrast, Stokes drift accounts for $33 \%$ of the total flux in MAL station implying that tides have a bigger influence in this region.

An analogue can be drawn to the San Joaquin branch, where VNS and STK experience only advective terms. At MOK and SJJ dispersive (20 and 63\%, respectively) and Stokes flux (5 and $11 \%$ ) start to influence the total flux (Fig. 10). The analyses of the three different flux components in smaller Delta channels show that river and tidal signals are equally important. The river peak signal is less important inside smaller channels than in rivers. At TMS, the dispersive flow accounts for $60 \%$ of the total flux.

The flux analyses show that there is no change in the Delta net circulation when comparing wet and dry seasons. There is not a major change in the flux direction when comparing the seasons. However, there is a change in importance of each flux component.

Figure 10 shows that dispersive flux and Stokes drift relative contributions vary seasonally. When river discharge is high the relative contribution of dispersive flux is lower than during low flow conditions. This pattern is more apparent at stations where the river signal is stronger. At RVB the dispersive flux contribution is about $15 \%$ during the wet season and $26 \%$ in the dry season; the same applies for MAL and STK. In smaller channels, like TMS and SJJ, the dispersive flux seasonal variation is milder, varying about $10 \%$, from

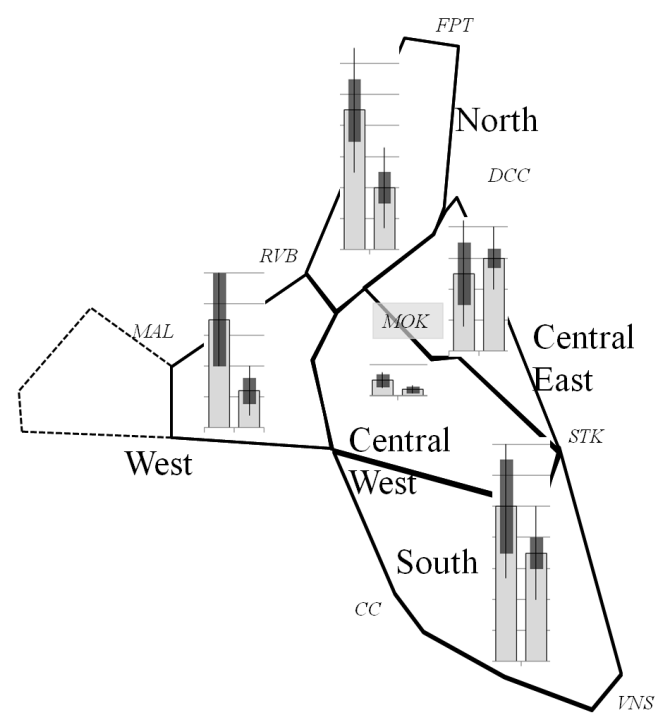

Figure 12. Turbidity in each Delta region. For each region, the left bars indicates wet season and the right bars the dry season. The light gray bars indicate the mean turbidity over the region, the darker bars the spatial deviation and the lines the daily deviation. Each horizontal line represents 10 NTU.

$55 \%$ in the wet season to $65 \%$ in the dry season. In the dry season the change in flux contributions, from advective to dispersive and Stokes drift, leads to a lower net export of sediment from the Delta, even though the concentrations in the Delta are only about $30 \mathrm{mg} \mathrm{L}^{-1}$.

\subsection{Sediment deposition pattern}

The flux changes from completely advective to dispersive and Stokes drift sheds some light on the Delta deposition areas. The places where the dispersive flux starts to play a role, near RVB and MOK, are the same places where net deposition is observed (Fig. 11). Other locations where considerable sedimentation takes place are in flooded island areas, such as Franks Tract and the Clifton court. The 2-D model is sufficient for such areas (Fig. 11).

The San Joaquin River downstream of Stockton experiences high deposition. This finding is confirmed by constant dredging needed to maintain the Stockton navigation channel. The river discharge modulates the deposition pattern in the main channels. In the Sacramento deposited sediment is gradually washed away and transported to the mud flats at the channel margins, until the next peak. At the flooded islands the sedimentation process is gradual and steady, erosion is not observed in these areas.

Deposition is primarily observed during the wet and dry season. Some exceptions occur in small bends in the Sacramento River that are erosional during the wet season and depositional during the dry season. The deposition pattern provides insight into the best areas for marsh restoration. 


\subsection{Turbidity}

So far the discussion presented is in terms of SSC levels for the standard run, budgets and fluxes, while ecological analysis is often based on turbidity levels. SSC and turbidity are correlated by rating curves as $\log 10(\mathrm{SSC})=a \cdot \log 10$ (Turb) $+b$, where $a$ and $b$ are local parameters empirically defined for each Delta area. For the northern area $a=0.85$ and $b=0.35$, central/western area $a=0.91$ and $b=0.29$, central/eastern $a=0.72$ and $b=0.26$, Southern $a=1.16$ and $b=0.27$ and Eastern $a=0.914$ and $b=0.29$ (USGS Sacramento, personal communication, 2014).

In this section we present average values for turbidity within a specific Delta region as well as its seasonal and daily variations (Fig. 12). Generally, the mean turbidity levels and spatial variations are higher during the wet season than during the dry season. During the wet season, the southern area had the highest mean value (50 NTU), and deviation (15 NTU), caused by a combination of large sediment supply and low flow velocities. The Northern region is the second most turbid area ( $45 \pm 10 \mathrm{NTU})$, where sediment transported by the Sacramento River flows in the channels, increasing the turbidity levels. The central-western region is the least turbid area ( $5 \pm 2 \mathrm{NTU})$ and, as previously shown, it has the highest trapping efficiency of the entire Delta. In the dry season the mean turbidity daily variation decreases in the entire Delta. The opening of the DCC during the dry season lets sediment from the Sacramento River enter these areas, increasing the mean turbidity level. The spatial distribution of the most turbid areas is the same as in the wet season. The daily deviation is mostly proportional to the turbidity level and to the distance from the sea. In the southern and western areas the daily variation is higher during the dry season. It shows that there is a strong tidal signal in these parts of the Delta.

The DCC and Georgina Slough (GLS) channels that connect the Sacramento and San Joaquin rivers are important bridges to export sediment from the Sacramento River to the eastern Delta. The smaller channels of the network play a minor role in the Delta sediment budget because the discharges in these channels are considerably smaller than in the rivers.

\subsection{Data input discussion}

As a well surveyed area that now has a complex processbased model, the Delta offers the opportunity to test how much data are necessary to develop a reliable sediment model. The model supports high temporal and spatial resolution and includes multiple physical processes such as bottom friction, sedimentation and erosion. The available data allow for calibration and validation of model results.

As presented above, with simple settings of one mud fraction and simple bed sediment availability the model is capable of representing the main sediment dynamics processes, the peak timing and duration, and results in a sediment bud- get. The data necessary for accurate modeling and forecasting are fine resolution bathymetry to correctly reproduce hydrodynamics, SSC and discharge at the inflow and outflow boundaries. It is necessary as well to have one to two stations in the domain in order to properly calibrate the model. The results from the calibrated model using these few data can be extrapolated for the entire domain, allowing for closing the sediment budget for the whole system.

The 2-D model results output is available in high temporal ( $\sim$ hours) and spatial $(\sim 20 \mathrm{~m})$ resolution, and the modeled water quality parameters can be used in other models or for descriptive purposes. With limited input data we can come to a detailed system description with considerable forecast capacity, expanding the applicability of this work to lessmeasured estuaries.

\section{Conclusions}

In this work we make a step towards understanding and simulating sediment dynamics from source to sink in a complex estuary. This work shows that it is possible to reproduce the main system sediment dynamics as well as construct an accurate detailed budget for complex areas such as the Delta using a 2-D process-based numerical model coupled with a water quality model.

Overall, the model reproduces the SSC peaks and event timing and duration (wet season) as well as the low concentration in dry season throughout the Delta, except at Mallard where the water column is stratified due to salt intrusion. Stratification issues are not solved in a 2-D model. For this reason we are working on a 3-D model in order to include the bay area, leading to a unique source to sink model.

The Delta has many observation stations. However, this work shows that substantial sediment is exported trough the pumping stations $\left(100 \mathrm{kt} \mathrm{yr}^{-1}\right)$ at the southern Delta where no data in SSC are available. This sediment export needs further investigation, since it is possible that it was deposited in the channels before the pumps.

We show that with simple sediment settings of one fraction at the input boundary and a simple distribution of bed sediment availability, it is possible to reproduce seasonal variations as well as construct a yearly sediment budget with more than $90 \%$ accuracy when compared with a data derived budget. It also shows that it is extremely important to have discharge and SSC measurements at least in the input boundaries and close to the system output in order to be able to calibrate the model settings applied for hydrodynamics and suspended sediment. This methodology now can be applied in less-measured estuaries.

Sediment is a key factor in the water quality and ecology of an estuary. The D3D FM software allows for direct coupling to water quality, sediment transport and habitat modeling. Our work provides the basis to a chain of models, which goes from the hydrodynamics, to suspended sediment, to phyto- 
plankton, to fish, clams and marshes. The turbidity and deposition pattern analysis may guide ecologists in future works to define areas of interest and/or venerable areas to be study, as well as guide data collecting efforts. The present model opens the possibility for forecast and operational modeling. Forecasting the time frame of high levels of SSC (turbidity) allows for planning of measurements campaigns for ecologists, as well as the possibility of tracking potentially contaminated sediment and be able to make a contingency plan as well as temporary barriers and pumping operations.
The Sacramento-San Joaquin delta is a typical case of a highly impacted estuary. Being able to numerically simulate and determine sediment transport, budget and turbidity levels in this type of environment open possibilities to better informed political, ecological and management decisions including how to respond to climate change and sea level rise. This type of model is an important management tool that is applicable to other impacted estuaries worldwide. 


\section{Appendix A: Hydrodynamic calibration}

The hydrodynamic calibration was carried out for 3month high river flow conditions (16 December 1999 to 16 March 2000) and a 3-month period of low river flow conditions (16 July 2001 to 16 October 2001). All data are in NAVD88 (vertical datum), UTM 10 (horizontal datum) and GMT (time reference).

Hourly measured water levels at Point Reyes (tidesandcurrents.noaa.gov/) were used as seaward boundary condition. Landward boundary conditions for the Sacramento River were obtained from daily measured river flow data at Freeport (FPT) and for the San Joaquin River near Vernalis (VNS) (cdec.water.ca.gov/). The inflow from the Yolo Bypass (YOLO) was approximated by curve fitting data from Qyolo and Qrsac.

Measured data for the bay area were obtained from tidesandcurrents.noaa.gov/, for part of the delta from the California Data Exchange Centre cdec.water.ca.gov/ and for stations with numbers from direct contact with the Department of Water Resources (DWR).
Calibration was carried out by systematically varying the value of the Manning's coefficient for different sub-areas of the Bay-Delta system. The calibration data analysis includes (local and time varying) influence of air pressure and wind in the definition of the boundary condition as well as in the calibration data inside the modeling domain. These may account for (part of) the error between measurements and modeling results. Also, the NAVD88 reference is not known for all measurement stations, although tidal water fluctuations may be modeled properly. To avoid these problems, a better method to assess the model performance is to focus on water level amplitude and phasing of the different tidal constituents. Boundary conditions, calibration data and model results are thus decomposed by Fourier transformation into tidal components which are then compared. By far, the main tidal constituents at Golden Gate (GGT) are O1, K1, N2, M2 and $\mathrm{S} 2$, with $\mathrm{M} 2$ being the largest. The model represents their values quite well. The difference in amplitude is $1.3 \%$ for M2, up to $14 \%$ for O1, but the phasing shows a maximum of only $3 \%(\mathrm{O} 1)$ ).

Figure A1 gives calibration results for the high and low river flow. The largest (extreme) deviations are explained by the fact that the measured water levels did not have a known reference to NAVD88 (http://www.d3d-baydelta.org/). 

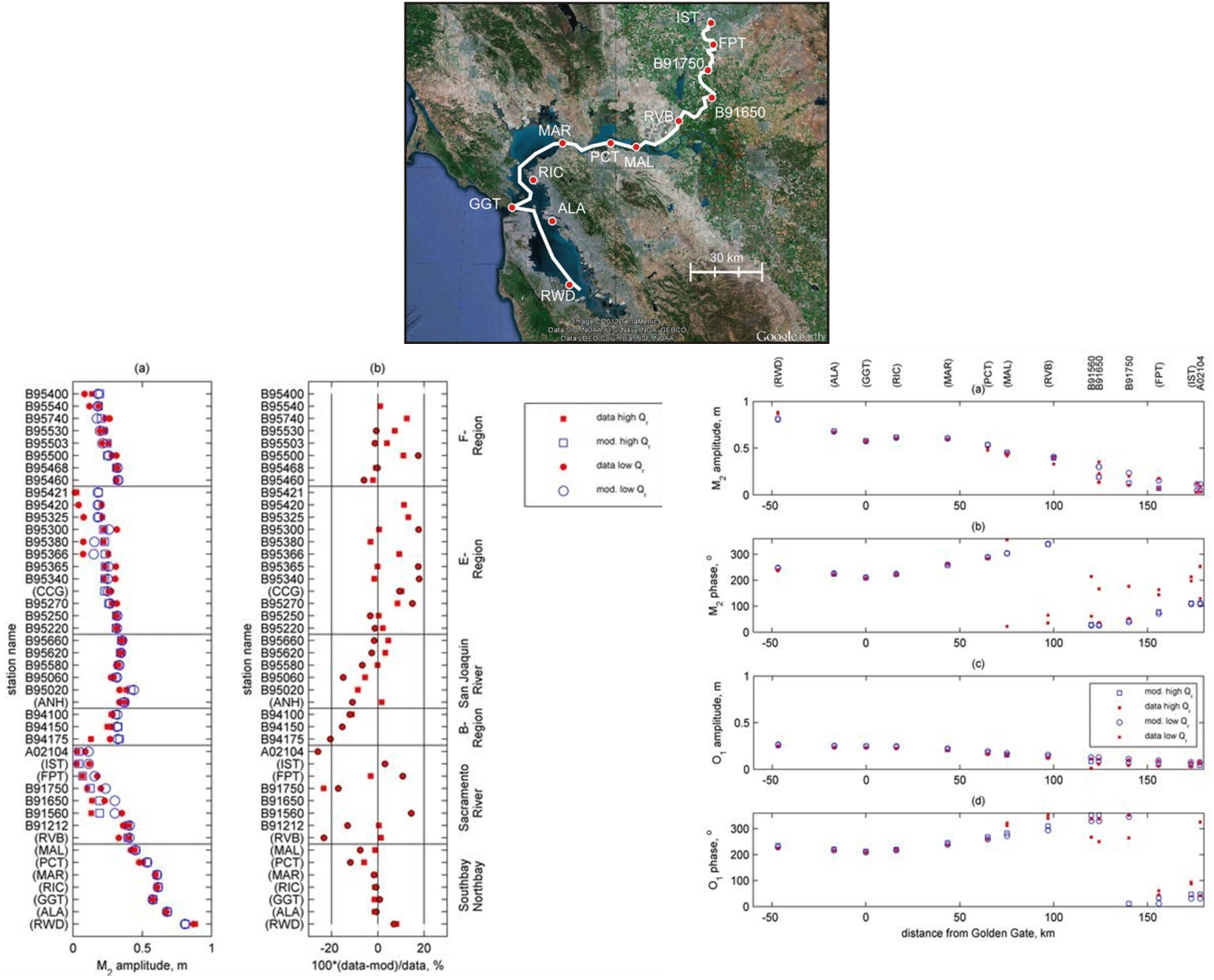

Figure A1. Hydrodynamic calibration example. 


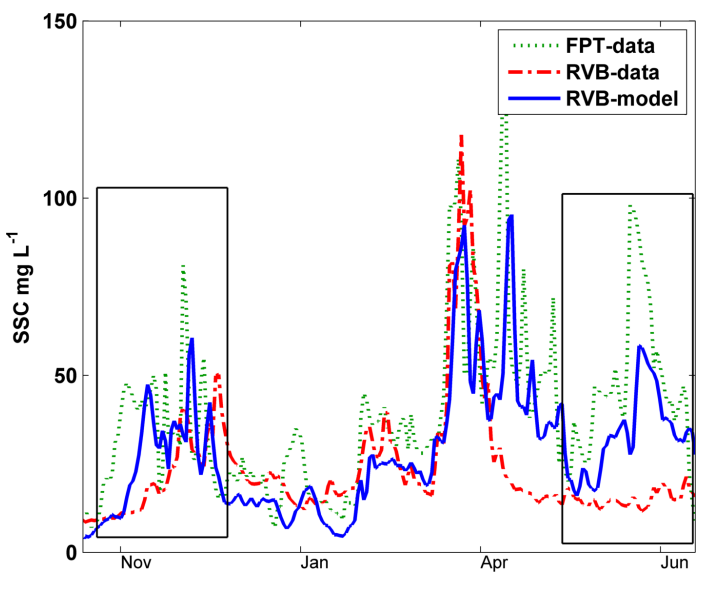

Figure B1. Comparison between SSC levels in RVB station in situ data (dashed red) and model result (solid blue) and FPT station (dotted green).

\section{Appendix B: SSC calibration}

All stations clearly reproduce SSC peaks during high river flow periods and lower concentrations during the remainder of the year (apart from MAL during the July-August period). The good representation of the peak timing means that the main delta event is reproduced by the model as well as the periods of delta clearance. These two periods are critical for ecological models, and a good representation generates robust input to ecological models. A closer look at Fig. 4 reveals differences between model results and data. These differences are discussed station by station in this Appendix.

At RVB, SSC levels are directly proportional to Sacramento River discharge (Fig. B3), and that the model properly represents the water discharge peak intensity and duration. However, in the model, the first peak, which occurs in October, remobilizes sediment faster than observed in the data. Analyzing the raw data, it is possible to observe a trend of SSC increase which the model overestimates. A probable explanation lies in the initial sediment composition of the bed. Defining the bottom sediment composition does not account for consolidation processes; therefore, the first peak comes after the dry season when the mud in the banks has consolidated. In the simulation case, when river discharge increases, it remobilizes non-consolidated bottom/bank sediment causing an earlier peak than in the data. Similar behavior is observed at STK in December. Sediment trapped in sub-aquatic vegetation and marshes could be another explanation for the slower increase of the first peak as the model discharges for both stations agree with data (Fig. 4).

Another difference between the data and the model results at RVB is the peak in May (second rectangle, Fig. B1), which is not observed in the data. SSC level at the RVB station is directly proportional to water discharge in FPT (Fig. B3, RVB). The May peak is observed in FPT and so should have been transported towards RVB just as the two preceding peaks.



Figure B2. Water discharge (model) and SSC level (data and model) in MOK station.

However, the data set does not reproduce this peak. One of the possible explanations is an error in measurements, since it comes after a major event and the equipment might be damaged. Other explanations could be a different composition of the suspended sediment properties and/or flocculation.

The model underestimates the first and second SSC peaks at MOK. However, the measured SSC signal is not consistent with the local water discharge signal. First, we checked that modeled water discharge is reproducing the local conditions, where data are available from mid-February onwards. The last peak in Fig. 4 (mid-March) shows that water discharge, in situ and modeled SSC have the same rage of variation. Therefore, the SSC levels are proportional to the local water discharge. Earlier, the January SSC data peak is much higher than the water discharge and the SSC level calculated in the model. The same happens in mid-February when no water discharge peak is observed but there is a peak in the SSC data. Again the peaks in SSC could be caused by an error in the measurements or local, diffuse input of sediment such as from local farm waste water or biological activity remobilizing the substrate.

The model represents the wet season SSC peaks well at MAL; however, during the three drier periods of the year the model underestimates SSC levels (Fig. B2). From the scatter plots of water discharge versus SSC (Fig. B3), it is possible to explain the weaker performance of the model during low river flow at MAL. These graphs represent river water discharge in FPT lagged by 2 days to SSC in RVB and MAL. Several time lags were tested, as MAL does not have a reasonable correlation with any of the time lags; it is presented here with the same time lag as the one for RVB. RVB station reflects a positive correlation between river discharge and SSC derived from in situ data and model results. The correlation coefficient $(R)$ at RVB is 0.58 .

At the MAL station $R=0.26$, showing that there is not a strong correlation between river discharge and SSC levels. The low correlation is due to high SSC levels during low water discharge periods, when the model underestimates SSC levels. Under low river discharges conditions, salt water in- 

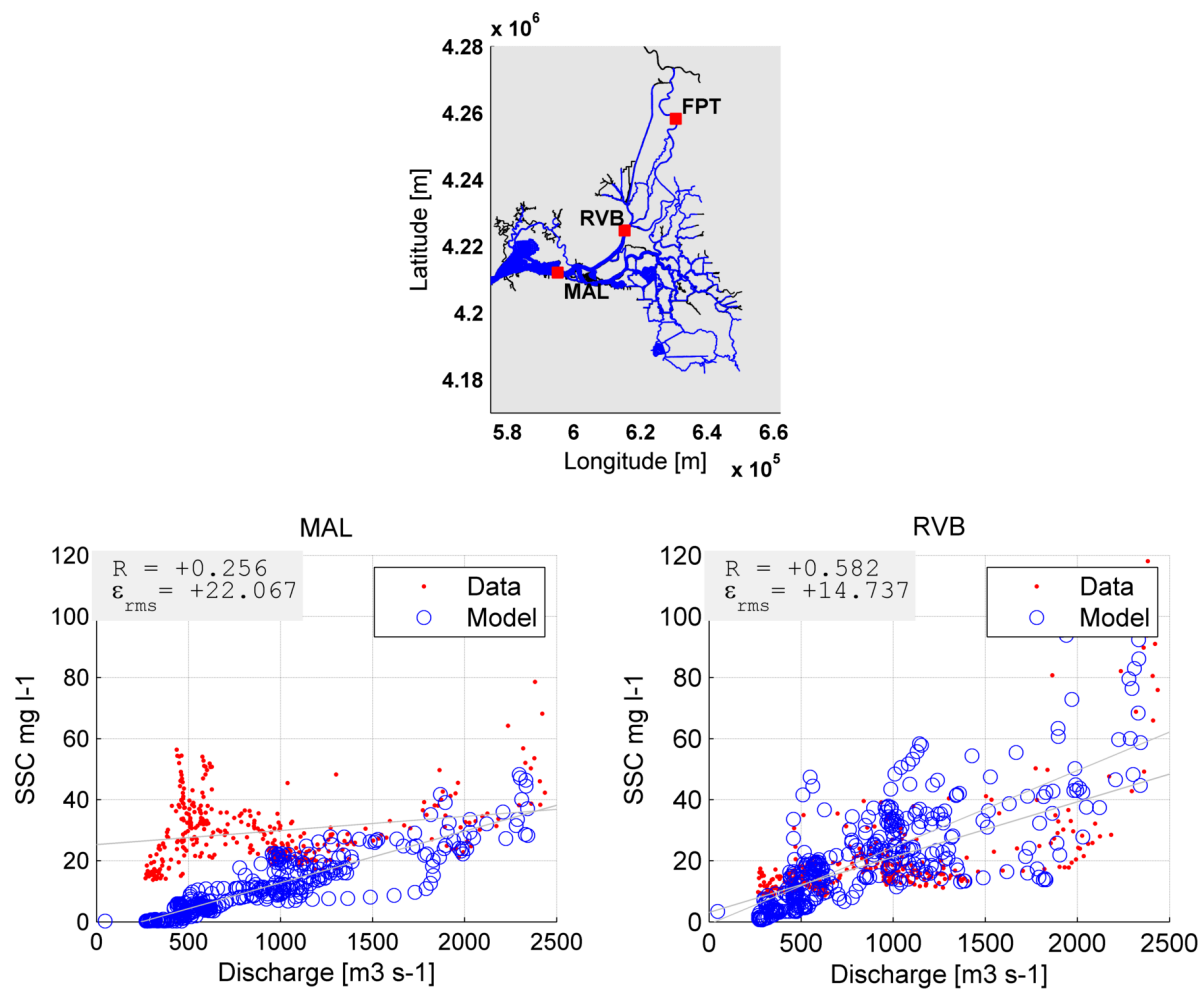

Figure B3. Scatter plot discharge versus SSC shown for MAL station on the left-hand (MAL) side and on the right-hand (RVB) side for RVB station. The red dots represent the data and the blue model results.

trudes into Suisun Bay leading to considerable stratification between fresh and salt water and shifting of the Estuarine Turbidity Maximum (ETM) landward (http://sfbay.wr.usgs. gov/access/wqdata/) (Brennan et al., 2002). In order to better model SSC levels for these conditions a 3-D model is needed at MAL. With these results we are still able to calculate sediment export, since most of the sediment export occurs in the wet period (McKee et al., 2006), when the model accurately reproduces measured SSC levels. 
Acknowledgements. The research is part of the US Geological Survey Computational Assessment of Scenarios of Change for the Delta Ecosystem (CASCaDE) climate change project (CASCaDE contribution 60). The authors acknowledge the US Geological Survey Priority Ecosystem Studies and California Federation Bay-Delta Program (CALFED) for making this research financially possible. The data used in this work are freely available on the USGS website (nwis.waterdata.usgs.gov). The model applied in this work will be freely available from http://www.d3d-baydelta.org/. We thank Tara Morgan-King, Scott Wright and David Schoellhamer for data collection and analysis. We thank David Schoellhamer for the constructive comments on the manuscript.

Edited by: P. Molnar

\section{References}

Ariathurai, R. and Arulanandan, K.: Erosion rates of cohesive soils, J. Hydrol. Eng. Div.-ASCE, 104, 279-283, 1978.

ASTM International: Standards on Disc, Section Eleven, Water and Environmental Technolog, PA, USA, 2002.

Baskerville, B. and Lindberg, C.: The Effect of Light Intensity, Alga Concentration, and Prey Density on the Feeding Behavior of Delta Smelt Larvae, American Fisheries Society Symposium, 219-227, 2004.

Barnard, P. L., Schoellhamer, D. H., Jaffe, B. E., and McKee, L. J.: Sediment transport in the San Francisco Bay coastal system: an overview, Mar. Geol., 345, 3-17, doi:10.1016/j.margeo.2013.04.005, 2013.

Bever, A. J. and MacWilliams, M. L.: Simulating sediment transport processes in San Pablo Bay using coupled hydrodynamic, wave, and sediment transport models, Mar. Geol., 345, 235-253, doi:10.1016/j.margeo.2013.06.012, 2013.

Brennan, M. L., Schoellhamer, D. H., Burau, J. R., and Monismith, S. G.: Tidal asymmetry and variability of bed shear stress and sediment bed flux at a site in San Francisco Bay, USA, Environmental Fluid Mechanics Laboratory, Dept. Civil \& Environmental Engineering, Stanford University, Stanford, CA, US Geological Survey, Placer Hall, Sacramento, CA, 2002.

Brown, L. R.: A Summary of the San Francisco Tidal Wetlands Restoration Series, San Francisco Estuary and Watershed Science, San Francisco, 2003.

Brown, L. R., Bennett, W., Wagner, R. W., Morgan-King, T., Knowles, N., Feyrer, F., Schoellhamer, D., Stacey, M., and Dettinger, M.: Implications for future survival of delta smelt from four climate change scenarios for the SacramentoSan Joaquin Delta, California, Estuar. Coast., 36, 754-774, doi:10.1007/s12237-013-9585-4, 2013.

Cappiella, K., Malzone, C., Smith, R., and Jaffe, B. E.: Sedimentation and Bathymetry Changes in Suisun Bay: 1867-1990, USGS, Menlo Park, 1999.

Casulli, V. and Walters, R. A.: An unstructured grid, threedimensional model based on the shallow water equations, Int. J. Numer. Meth. Fluids, 32, 331-348, doi:10.1002/(sici)10970363(20000215)32:3<331::aid-fld941>3.0.co;2-c, 2000.
Cole, B., Cloern, J., and Alpine, A.: Biomass and productivity of three phytoplankton size classes in San Francisco Bay, Estuaries, 9, 117-126, doi:10.2307/1351944, 1986.

Conomos, T. J., Smith, R. E., and Gartner, J. W.: Environmental setting of San Francisco Bay, Hydrobiologia, 129, 1-12, doi:10.1007/BF00048684, 1985.

Davidson-Arnott, R. G. D., van Proosdij, D., Ollerhead, J., and Schostak, L.: Hydrodynamics and sedimentation in salt marshes: examples from a macrotidal marsh, Bay of Fundy, Geomorphology, 48, 209-231, doi:10.1016/S0169-555X(02)00182-4, 2002.

Delta Atlas: Sacramento - San Joaquin Delta Atlas, DWR - Department of Water Resources, California, USA, 1995.

Deltares: D-Flow Flexible Mesh, Technical Reference Manual, Deltares, Delft, 82 pp., 2014.

Downing, J.: Twenty-five years with OBS sensors: the good, the bad, and the ugly, Cont. Shelf. Res., 26, 2299-2318, doi:10.1016/j.csr.2006.07.018, 2006.

Dyer, K. R.: The salt balance in stratified estuaries, Estuar. Coast. Mar. Sci., 2, 273-281, doi:10.1016/0302-3524(74)900176, 1974.

Foxgrover, A., Smith, R. E., and Jaffe, B. E.: http://sfbay.wr.usgs. gov/sediment/delta/, last access: October 2012.

Ganju, N. K. and Schoellhamer, D. H.: Annual sediment flux estimates in a tidal strait using surrogate measurements, Estuar. Coast. Shelf S., 69, 165-178, doi:10.1016/j.ecss.2006.04.008, 2006.

Ganju, N. K. and Schoellhamer, D. H.: Calibration of an estuarine sediment transport model to sediment fluxes as an intermediate step for simulation of geomorphic evolution, Cont. Shelf. Res., 29, 148-158, doi:10.1016/j.csr.2007.09.005, 2009.

Ganju, N. K., Schoellhamer, D. H., and Jaffe, B. E.: Hindcasting of decadal-timescale estuarine bathymetric change with a tidal-timescale model, J. Geophys. Res., 114, F04019, doi:10.1029/2008jf001191, 2009.

Gibbs, R. J. and Wolanski, E.: The effect of flocs on optical backscattering measurements of suspended material concentration, Mar. Geol., 107, 289-291, doi:10.1016/00253227(92)90078-V, 1992.

Gilbert, G. K.: Hydraulic-Mining Debris in the Sierra Nevada, Professional Paper 105, USGS, Califronia, USA, 154 pp., 1917.

Hayes, T. P., Kinney, J. J., and Wheeler, N. J.: California Surface Wind Climatology, California Air Resources Board, Aerometric Data Division, California, USA, 107 pp., 1984.

Hervouet, J.-M.: Hydrodynamics of Free Surface Flows, John Wiley \& Sons, Ltd, 1-360, 2007.

Jaffe, B. E., Smith, R., and Torresan, L.: Sedimentation and Bathymetric Change in San Pablo Bay: 1856-1983, USGS, Menlo Park, 1998.

Jaffe, B. E., Smith, R. E., and Foxgrover, A. C.: Anthropogenic influence on sedimentation and intertidal mudflat change in San Pablo Bay, California: 1856-1983, Estuar. Coast. Shelf S., 73, 175-187, doi:10.1016/j.ecss.2007.02.017, 2007.

Janauer, G. A.: Ecohydrology: fusing concepts and scales, Ecol. Eng., 16, 9-16, doi:10.1016/S0925-8574(00)00072-0, 2000.

Jassby, A. D., Cloern, J. E., and Powell, M. A.: Organic carbon sources and sinks in San Francisco Bay: variability induced by river flow, Mar. Ecol.-Prog. Ser., 95, 39-54, 1993.

Jassby, A. D., Cloern, J. E., and Cole, B. E.: Annual primary production: Patterns and mechanisms of change in a nutrient-rich 
tidal ecosystem, Limnology and Oceanography, 47, 698-712, doi:10.4319/lo.2002.47.3.0698, 2002.

Kernkamp, H. W. J., Van Dam, A., Stelling, G. S., and De Goede, E. D.: Efficient scheme for the shallow water equations on unstructured grids with application to the Continental Shelf, Ocean Dynam., 29, 1175-1188, doi:10.1007/s10236-011-0423-6, 2010.

Kimmerer, W.: Open water processes of the San Francisco estuary: from physical forcing to biological responses, San Francisco Estuary and Watershed Science, San Francisco, 2 pp., 2004.

Kineke, G. C. and Sternberg, R. W.: Measurements of high concentration suspended sediments using the optical backscatterance sensor, Mar. Geol., 108, 253-258, doi:10.1016/00253227(92)90199-R, 1992.

Kirwan, M. L., Guntenspergen, G. R., D’Alpaos, A., Morris, J. T., Mudd, S. M., and Temmerman, S.: Limits on the adaptability of coastal marshes to rising sea level, Geophys. Res. Lett., 37, L23401, doi:10.1029/2010g1045489, 2010.

Krone, R. B.: Flume Studies of the Transport of Sediment in Estuarial Shoaling Processes, University of California, Berkeley, California, 1962.

Ludwig, F. L. and Sinton, D.: Evaluating an objective wind analysis technique with a long 25 record of routinely collected data, J. Appl. Meteorol., 39, 335-348, doi:10.1175/15200450(2000)039<0335:eaowat>2.0.co;2, 2000.

Ludwig, K. A. and Hanes, D. M.: A laboratory evaluation of optical backscatterance suspended solids sensors exposed to sand-mud mixtures, Mar. Geol., 94, 173-179, doi:10.1016/00253227(90)90111-V, 1990.

Manh, N. V., Dung, N. V., Hung, N. N., Merz, B., and Apel, H.: Large-scale suspended sediment transport and sediment deposition in the Mekong Delta, Hydrol. Earth Syst. Sci., 18, 30333053, doi:10.5194/hess-18-3033-2014, 2014.

Manning, A. J. and Schoellhamer, D. H.: Factors controlling floc settling velocity along a longitudinal estuarine transect, Mar. Geol., 345, 266-280, doi:10.1016/j.margeo.2013.06.018, 2013.

McKee, L. J., Ganju, N. K., and Schoellhamer, D. H.: Estimates of suspended sediment entering San Francisco Bay from the Sacramento and San Joaquin Delta, San Francisco Bay, California, J. Hydrol., 323, 335-352, doi:10.1016/j.jhydrol.2005.09.006, 2006.

McKee, L. J., Lewicki, M., Schoellhamer, D. H., and Ganju, N. K.: Comparison of sediment supply to San Francisco Bay from watersheds draining the Bay Area and the Central Valley of California, Mar. Geol., 345, 47-62, doi:10.1016/j.margeo.2013.03.003, 2013.

Milliman, J. D. and Syvitski, J. P. M.: Geomorphic/tectonic control of sediment discharge to the ocean: the importance of small mountainous rivers, J. Geol., 100, 525-544, doi:10.1086/629606, 1992.

Morgan-King, T. and Schoellhamer, D.: Suspended-sediment flux and retention in a backwater tidal slough complex near the landward boundary of an estuary, Estuar. Coast., 36, 300-318, doi:10.1007/s12237-012-9574-z, 2013.

Morris, J. T., Sundareshwar, P. V., Nietch, C. T., Kjerfve, B., and Cahoon, D. R.: Responses of coastal wetlands to rising sea level, Ecology, 83, 2869-2877, doi:10.1890/00129658(2002)083[2869:ROCWTR]2.0.CO;2, 2002.
Reed, D.: Sea-level rise and coastal marsh sustainability: geological and ecological factors in 20 the Mississippi delta plain, Geomorphology, 48, 233-243, 2002.

Schoellhamer, D. H.: Variability of suspended-sediment concentration at tidal to annual time scales in San Francisco Bay, USA, Cont. Shelf. Res., 22, 1857-1866, doi:10.1016/S02784343(02)00042-0, 2002.

Schoellhamer, D. H.: Sudden clearing of estuarine waters upon crossing the threshold from transport to supply regulation of sediment transport as an erodible sediment pool is depleted: San Francisco Bay, 1999, Estuar. Coast., 34, 885-899, doi:10.1007/s12237-011-9382-x, 2011.

Schoellhamer, D. H., Wright, S. A., and Drexler, J.: A Conceptual Model of Sedimentation in the Sacramento-San Joaquin Delta, San Francisco Estuary and Watershed Science, http: //escholarship.org/uc/item/2652z8sq (last access: June 2015), 2012.

Sutherland, T. F., Lane, P. M., Amos, C. L., and Downing, J.: The calibration of optical backscatter sensors for suspended sediment of varying darkness levels, Mar. Geol., 162, 587-597, doi:10.1016/S0025-3227(99)00080-8, 2000.

Syvitski, J. P. M. and Kettner, A. J.: Sediment flux and the Anthropocene, Philos. T. Roy. Soc. A, 369, 957-975, doi:10.1098/rsta.2010.0329, 2011.

van der Wegen, M., Jaffe, B. E., and Roelvink, J. A.: Process-based, morphodynamic hindcast of decadal deposition patterns in San Pablo Bay, California, 1856-1887, J. Geophys. Res.-Earth, 116, F02008, doi:10.1029/2009jf001614, 2011.

Vörösmarty, C. J., Meybeck, M., Fekete, B., Sharma, K., Green, P., and Syvitski, J. P. M.: Anthropogenic sediment retention: major global impact from registered river impoundments, Global Planet. Change, 39, 169-190, doi:10.1016/S09218181(03)00023-7, 2003.

Whipple, A., Grossinger, R., Rankin, D., Stanford, B., and Askevold, R.: Sacramento-San Joaquin Delta historical ecology investigation: exploring patterns and process, San Francisco Estuary Institute - Aquatic Science Center, Richmond, CA, 2012.

Whitcraft, C. R. and Levin, L. A.: Regulation of benthic algal and animal communities by salt marsh plants: impact of shading, Ecology, 88, 904-917, doi:10.1890/05-2074, 2007.

Willmott, C. J.: On the validation of models, Phys. Geogr., 2, 184194, doi:10.1080/02723646.1981.10642213, 1981.

Winterwerp, J. C., Manning, A. J., Martens, C., de Mulder, T., and Vanlede, J.: A heuristic formula for turbulence-induced flocculation of cohesive sediment, Estuar. Coast. Shelf Sci., 68, 195-207, doi:10.1016/j.ecss.2006.02.003, 2006.

Wright, S. A. and Schoellhamer, D. H.: Trends in the sediment yield of the Sacramento River, California, 1957-2001, San Francisco Estuary and Watershed Science, http://repositories.cdlib. org/jmie/sfews/vol2/iss2/art2 (last access: June 2015), 2004.

Wright, S. A. and Schoellhamer, D. H.: Estimating sediment budgets at the interface between rivers and estuaries with application to the Sacramento-San Joaquin River Delta, Water Resour. Res., 41, W09428, doi:10.1029/2004wr003753, 2005.

Yahg, S. L.: The role of scirpus marsh in attenuation of hydrodynamics and retention of fine sediment in the Yangtze estuary, Estuar. Coast. Shelf S., 47, 227-233, 1998. 